\title{
A Workflow to Investigate the Impacts of Weathered Multi-Walled Carbon Nanotubes to the Mudsnail Lymnaea Stagnalis
}

Katrin Weise ( $\square$ katrin.weise1@tu-dresden.de)

Institute for Hydrobiology TU Dresden: Technische Universitat Dresden

Thomas Kurth

Center for Molecular and Cellular Bioengineering Technische Universität Dresden

Irina Politowski

Institute for Environmental Research RWTH Aachen University

Carola Winkelmann

Institute for Integrated Natural Sciences Universität Koblenz-Landau

Andreas Schäffer

Institute for Environmental Research RWTH Aachen University

\section{Susanne Kretschmar}

Center for Molecular and Cellular Bioengineering Technische Universität Dresden: Technische Universitat

Dresden

\section{Thomas Ulrich Berendonk}

Institute for Hydrobiology Technische Universität Dresden: Technische Universitat Dresden

\section{Dirk Jungmann}

Institute for Hydrobiology Technische Universität Dresden: Technische Universitat Dresden

\section{Research Article}

Keywords: L. stagnalis, benthic biofilm, CNTs, wMWCNTs, enrichment, physiological state, histology

Posted Date: June 4th, 2021

DOl: https://doi.org/10.21203/rs.3.rs-472447/v1

License: (c) (i) This work is licensed under a Creative Commons Attribution 4.0 International License.

Read Full License 


\section{Abstract}

Although the development and application of nanomaterials is a growing industry, little data is available on the ecotoxicological effects on aquatic organisms. Therefore, we set up a workflow to address the potential uptake of weathered multi-walled carbon nanotubes (wMWCNTs) by a model organism, the pulmonary mudsnail Lymnaea stagnalis (L. stagnalis), which plays an important role in the food web. It represents a suitable organism for this approach because as a grazer it potentially ingests large amounts of sedimented wMWCNTs. As food source for $L$. stagnalis, benthic biofilm was investigated by the use of a transmission electron microscope (TEM), and a scanning electron microscope (SEM) after exposure with wMWCNTs. In addition, isotopic labeling was applied with ${ }^{14} \mathrm{C}$-wMWCNTs $(0.1 \mathrm{mg} / \mathrm{L})$ to quantify fate, behavior and enrichment of ${ }^{14} \mathrm{C}$-wMWCNTs in benthic biofilm and in L. stagnalis. Enrichment in benthic biofilm amounted to $529.0 \mu \mathrm{g}$ wMWCNTs/g dry weight and in L. stagnalis to $79.6 \mu \mathrm{g}$ WMWCNTs/g dry weight. A bioconcentration factor (BCF) for $L$. stagnalis was calculated $(3,500 \mathrm{~L} / \mathrm{kg})$. We demonstrate the accumulation of WMWCNTs $(10 \mathrm{mg} / \mathrm{L})$ in the digestive tract of $L$. stagnalis in an effect study. Moreover, the physiological markers glycogen and triglycerides as indicators for the physiological state, as well as the RNA/DNA ratio as growth indicator were examined. No significant differences between exposed and control animals were analyzed for glycogen and triglycerides after $24 \mathrm{~d}$ of exposure, but a decreasing trend is recognizable for triglycerides. In contrast, the significant reduction in the RNA/DNA ratio of $L$. stagnalis indicated an inhibition of growth with a following recovery after depuration. The described workflow enables a comprehensive determination of the fate and the behavior of WMWCNTs in specifically and in general all kinds of CNT in the aquatic environment and therefore contributes to a holistic risk assessment of wMWCNTs.

\section{Introduction}

Nanotechnology is an increasing sector in industry with a wide range of applications such as drug delivery, health care products or textiles (Baun et al. 2008; Bianco et al. 2005; Schwirn and Völker 2016). One product line are CNTs which can be divided into three main groups: single-, double-, and multi-walled carbon nanotubes (SWCNTs, DWCNTs, and MWCNTs, Petersen et al. 2011). CNTs, especially MWCNTs, are described to be the star in the nanomaterials industry (Sebastian, Arruebo and Santamaria 2013). These groups are found in wastewater at concentrations between $3.69-32.66 \mathrm{ng} / \mathrm{L}$, whereas a range of $0.001-0.8 \mathrm{ng} / \mathrm{L}$ has been detected in surface waters (Maurer-Jones et al. 2013) but environmental concentrations of nanomaterials in general are widely unknown (Lawrence et al. 2016). Due to agglomeration and sedimentation, over time, CNTs deposit in water and therefore cause higher concentrations in sludge and sediment (Chen et al. 2010; Schierz et al. 2014; Glomstad et al. 2018; Gottschalk et al. 2009; Sun et al. 2014; Politowski et al. 2021a). For this, reported CNT concentrations in sediment compartments range between $1 \mu \mathrm{g} / \mathrm{kg}$ and $1 \mathrm{mg} / \mathrm{kg}$ (Selck et al. 2016).

CNTs are attributed to their special sorption characteristics (Mueller and Nowack 2008; Petersen et al. 2016). Depending on $\mathrm{pH}$, temperature or redox processes, CNTs are able to adsorb hydrophobic environmental chemicals, which might promote a deviant accumulation behavior in the environment, for 
both the sorbent and the sorbate. MWCNTs directly reach the aquatic environment via, e.g., industrial production, whereas the indirect introduction occurs via sewage and landfill leachates (Petersen et al. 2011). The structure of MWCNTs in the aquatic environment is affected by natural processes, like oxidative photochemical or bacterial degradation (Klaine et al. 2008) accompanied with aging effects due to irradiation. Hence, it is crucial to understand the fate and behavior of MWCNTs in the environment. For this, combined experiments for hazard analysis of these interactions and accumulation properties of wMWCNTs must be established.

Organisms in the aquatic environment are basically exposed via two pathways, uptake via water (bioconcentration) or food (biomagnification). Taking fate and behavior of MWCNTs into account for hazard identification, an experimental design is needed which considers relevant organisms and food web interactions (Mortimer et al. 2016; Cano et al. 2018). In lakes and rivers, benthic biofilms with their microbial community (Characklis et al. 1982) play a considerable role in the food web. Such biofilms consist of taxa from many different phyla including bacteria, algae (e.g., diatoms), fungi, ciliates, cyanobacteria, rotifers, and nematodes (Kohušová et al. 2011). For single species, numerous publications on the effects of CNTs on these organisms exist, but effects on interactions or the transfer of CNTs within the food web have been less investigated (Politowski et al. 2021a). Organisms depending on biofilm as food source belong, e.g., to the functional feeding group of grazers. Different macroinvertebrates appertain to this group, especially snails and mayflies. By combining biofilm and grazers in an experimental approach, the impact of MWCNTs on the food web transfer of MWNCTs as well as their distribution, behavior and accumulation can be analyzed for hazard assessment. In order to consider environmental aging processes of nanomaterials, in our study, we focused on wMWCNTs.

The first step in our study was to investigate possible structural differences between wMWCNTs and pristine MWCNTs (MWCNTs) and additionally the enrichment of wMWCNTs in benthic biofilm. The impact of MWCNTs on primary producers, stress phenomena, and changes in the composition of algal cells were investigated in various publications (Long et al. 2012; Rhiem et al. 2015; Schwab et al. 2011; Wang et al. 2019; Politowski et al. 2021b). However, higher-tier approaches have been neglected and the available approaches are not necessarily applicable to investigate food web interactions. For primary consumers, such as the water flea Daphnia magna it has been shown that CNTs can accumulate in their body and that depuration is delayed in the absence of food (Petersen et al. 2009; Tervonen et al. 2010; Politowski et al. 2021b). It has also been shown that CNTs from food matrix, or sediment, are accumulated in aquatic invertebrates (Li et al. 2010; Wang et al. 2014; Petersen et al. 2008; Parks et al. 2013). For fish, quick uptake, accumulation and depuration of CNTs in the intestine have been shown, while only a few fragments of CNTs reached the blood system and muscle tissue (Maes et al. 2014a). Therefore, a more comprehensive assessment of environmental risks for animals are highly relevant due to their ability to enrich MWCNTs contingent on the key role in the food web.

Thus, the second step was to include a primary consumer into the test approach that feed directly on benthic biofilms. The freshwater snail Lymnaea stagnalis (Gratropoda: Lymnaeidae) was selected as test organism, due to its wide distribution in standing and flowing waters of the northern hemisphere and its 
crucial role in the aquatic and rural food web (Nyström and Pérez 1998, Orr et al. 2007). Moreover, it has been described that invertebrates found to be more sensitive than vertebrates (Jackson et al. 2013). L. stagnalis ingests all kinds of contaminated material from biofilms and it is vulnerable to dissolved or particle-adsorbed pollutants (Lance et al. 2010). Because of their high sensitivity towards toxins, over the past two decades this species has been proven particularly useful to study the toxicological effects of aquatic contaminants (Amorim et al. 2019). Thus, it is an ideal model for our investigations.

Furthermore, we want to know the fate of accumulated wMWCNTs in L. stagnalis and their distribution in the organism because after ingestion and passage through the esophagus, food reaches the strongly twisted intestine, which is covered by the digestive gland and where the intracellular digestion takes place. We monitored the accumulated wMWCNTs in the lumen of the intestinal tract by histological analyzes and its potential association with gut epithelial cells using TEM.

\section{Materials And Methods}

Microcosm and established benthic biofilm. One microcosm system (Fig. 1, a) for both test studies (quantification and effect study) consisted of 16 glass aquaria $(10 \times 14.4 \times 11 \mathrm{~cm})$. Experiments took place in air-conditioned laboratories at a constant temperature of $20 \pm 1^{\circ} \mathrm{C}$ with a light/dark cycle of $12 / 12 \mathrm{~h}$. For quantification and effect studies, the benthic biofilm was sampled in the Gauernitzbach, a secondorder mountain stream of $4.6 \mathrm{~km}$ length and tributary of the River Elbe, which has been described in detail by Winkelmann and Koop (2007). The stream catchment is moderately affected by urban and rural impacts (Kroll et al. 2016). By scraping off stones from the stream some biofilm was obtained. The harvested biofilm was then further treated as described by Rybicki et al. (2012). A mixed solution of biofilm suspension and Borgmann medium in a ratio of 3:1 (biofilm suspension:Borgmann medium) was applied to ensure a better adhesion and growth of the biofilm. This solution was modified for the quantification and effect study with one-eighth of the amount of $\mathrm{CaCO}_{3}$ compared to Borgmann (1996) due to adsorption properties (Kroll et al. 2016; Rybicki et al. 2012), in both test studies. An aliquot was added to each aquarium, where it was allowed to sediment to the bottom for $24 \mathrm{~h}$ prior to the test start of the quantification and effect study, respectively.

Test substance wMWCNT. The applied test substance was identified via SEM with their typically crosslink structure (Fig. 1, b). Synthesis and weathering of wMWCNTs. MWCNTs (Baytubes C 150 P, BTS, Leverkusen, Germany) were purchased from Bayer MaterialScience AG 2007 (details are depicted in Table 1). The ${ }^{14} \mathrm{C}$ radiolabeled MWCNTs were synthesized as described by Maes et al. (2014a) and Rhiem et al. (2015) at the Institute for Environmental Research at RWTH Aachen in collaboration with Bayer Technology Services GmbH (BTS, Leverkusen, Germany). Afterwards, ${ }^{14} \mathrm{C}-\mathrm{MWCNT}$ were purified using $12.5 \%$ hydrochloric acid solution to remove residual metal catalyst. Weathering of labeled and nonlabeled MWCNTs was performed in a Sunset CPS + apparatus (ATLAS Materials Testing Solutions) applying ultraviolet radiation for about three months $(65 \mathrm{~W} / \mathrm{m} 2=504,440 \mathrm{~kJ} / \mathrm{m} 2)$. The specific radioactivity of the weathered ${ }^{14} \mathrm{C}$-wMWCNTs was $1.66 \mathrm{MBq} / \mathrm{mg}$ (corresponding to $99,858 \mathrm{dpm} / \mu \mathrm{g}$ ). For 
more details on determination of specific radioactivity and characterization of ${ }^{14} \mathrm{C}$-wMWCNTs see Politowski et al. (2021a/b).

Table 1

Properties of the appointed MWCNTs (Baytubes, purity of $>95 \%$ ), divided by values and units.

\begin{tabular}{|lll|}
\hline & Value & Unit \\
\hline Number of walls & $3-15$ & - \\
\hline Outer diameter distribution & $5-20$ & $\mathrm{~nm}$ \\
\hline Inner diameter distribution & $2-6$ & $\mathrm{~nm}$ \\
\hline Length & $1-10$ & $\mu \mathrm{m}$ \\
\hline Bulk density & $140-160$ & $\mathrm{~kg} / \mathrm{m}^{3}$ \\
\hline
\end{tabular}

Test organism L. stagnalis. Living individuals of L. stagnalis (Fig. 1, c) were obtained from the breeding station INRA (French National Institute for Agricultural Research, France) for all experiments. They were reared in Borgmann medium according to the recipe of LO-4S E + H (Borgmann 1996) and fed 3 to 4 times a week with small pieces of organic cucumber and organic salad. The medium in the aquaria was renewed once a week with fresh Borgmann medium. Before starting the quantification and effect study, the mollusks were adapted three weeks to Borgmann medium modified with one-eighth of the amount of $\mathrm{CaCO}_{3}$ (Borgmann 1996; Kroll et al. 2016; Rybicki et al. 2012). All further physical parameters were applied according to the OECD guideline of reproduction tests for $L$. stagnalis (OECD 2016). For the quantification and effect studies, 160 animals with a mean shell length of $11.5 \pm 2.4 \mathrm{~mm}$ were used, i.e., 80 individuals being taken per test study. Oxygen was introduced into the aquaria at $16 \mathrm{~L} / \mathrm{min}$ via a Pasteur pipette, which was mounted on a tube and an air pump (Hailea Aco 9630) to ensure not less than $60 \%$ of oxygen during the whole experiments.

General experimental set-up. The two different test studies (Fig. 1) were accompanied by mortality investigation. The quantification study (bioconcentration) was carried out with labeled ${ }^{14} \mathrm{C}$-wMWCNTs in benthic biofilm during $168 \mathrm{~h}$ and $L$. stagnalis during $72 \mathrm{~h}$. The effect study was realized with unlabeled MWCNTs over $52 \mathrm{~d}$ whereby an exposure time for $24 \mathrm{~d}$ and a following depuration about $28 \mathrm{~d}$ was implemented. This study was divided into physiological and histology methods accompanied with prior performed microscopy between wMWCNT and MWCNT structure, benthic biofilm and L. stagnalis. Controls were examined parallel to all methods.

Quantification study. Quantification of ${ }^{14} \mathrm{C}$-wMWCNT uptake in benthic biofilm. A fresh prepared stock dispersion with a concentration of $0.1 \mathrm{mg} / \mathrm{L}{ }^{14} \mathrm{C}$-wMWCNTs was chosen. For this, a total amount of 1.014 $\mathrm{mg}{ }^{14} \mathrm{C}$-wMWCNT agglomerates was weighed using a microbalance (RADWAG, DE), transferred to a flask and filled with $101.4 \mathrm{~mL}$ distilled water. Afterwards a dispersion for 10 min by an ultrasonic probe (Sonopuls HD 2070, 70 W, pulse: 0.2 s, pause: 0.8 s, Bandelin, Germany) was applied. After sonication, 1 
$\mathrm{mL}$ of the stock dispersion was transferred into a vial, filled with LSC cocktail in a ratio of 1:1 (Perkin, Elmer, Ultima Gold XR, 6013119) and measured by using the Liquid Scintillation Analyser (LSC, Hidex $600 / 300 \mathrm{SL}$, Finland). For each sampling point (4 h, 24 h, $120 \mathrm{~h}$ and $168 \mathrm{~h}$ ), including four replicates, 20.4 $\mathrm{mL}$ from the stock dispersion (described above) was transferred to $999.6 \mathrm{~mL}$ freshly prepared modified Borgmann medium and dispersed again as aforementioned. All samples of ${ }^{14} \mathrm{C}$-wMWCNT were measured by taking five aliquots of $1 \mathrm{~mL}$ using the LSC (see above), directly after sonication.

The supernatant in the aquaria of prior bonded biofilm was removed with a custom-made glass U-tube. To obtain a volume of $400 \mathrm{~mL}$ as abovementioned, a volume of $200 \mathrm{~mL}$ from the ${ }^{14} \mathrm{C}$-wMWCNT dispersion together with $200 \mathrm{ml}$ fresh Borgmann medium was added to each aquarium. Thereby, the solution was carefully poured along the aquarium glass wall. Sampling was performed in four aquaria as replicates, respectively. Initially the whole water body from each aquarium was removed as described above. A syringe attached to the glass U-tube was used to suck the water phase out of the aquarium, without whirling up the biofilm. After that, the whole water phase was transferred to a $500 \mathrm{~mL}$ Schott flask. Subsequently, the water phase was dispersed again for 10 minutes by sonication (see above). Afterwards, five aliquots of $10 \mathrm{~g}$ from each Schott flask were drawn from the water phase and measured again by means of LSC. The remaining biofilm was completely scraped out of the aquaria with a spatula and dried for $24 \mathrm{~h}$ in a petri dish at $100^{\circ} \mathrm{C}$ in a drying cabinet (Memmert, DE). Afterwards the whole dried biofilm was weighed (analytical balance, Sartorius MC1 AC210S) and split into three vials (10 mL). After that, the vials were filled with LSC cocktail in a ratio of 1:1 and measured by means of LSC. Additionally, each whole aquarium was aspired, to collect all the radioactivity of the residuals. Residuals were consisted of three parts. The first part was the phase, consisting of the supernatant fluid that could not harvested with the glass U-tube before scraping out the biofilm. Second, the aquaria were wiped out with a cellulose cloth imbued with methanol (VWR, Germany) for two times, and third the radioactivity adsorbed to the Pasteur pipette, which was in contact with the water phase for applying oxygen. A recovery rate was calculated for the whole experimental set-up to obtain the quantity of all radioactivity of each aquarium.

In addition, a risk quotient (RQ) for the risk assessment was calculated with the following equation (Eq. 1): $R Q=P E C / P N E C$, whereby $R Q$ is classified as the risk characterization ratio. This ratio is calculated by dividing the predicted or measured environmental concentration (PEC or MEC, $\mathrm{mg} / \mathrm{L}$ ) through the extrapolated effect concentration (predicted no effect concentration; PNEC, mg/L), (Mathes 1997). An uncertainty factor to extrapolate the PNEC from the lowest found effect value depends on existing data for MWCNTs and described in detail by the Technical Guidance Document (TGD 2003).

Quantification of ${ }^{14} \mathrm{C}$-wMWCNT uptake in L. stagnalis. For the stock dispersion in the quantification study with L. stagnalis, a total amount of $1356 \mathrm{mg}{ }^{14} \mathrm{CWMWCNTs}$ was weighed for the sampling points (4 h, 24 $\mathrm{h}, 48 \mathrm{~h}$ and $72 \mathrm{~h}$ ) and dispersed in $135.6 \mathrm{~mL}$ distilled water. The same procedure was used as for benthic biofilm but with shorter incubation times ( $4 h, 24 h, 48 h$ and $72 h$ ) to prevent starvation of the animals as well as the samples of ${ }^{14} \mathrm{C}$-wMWCNT were measured after sonication (described above). 
Additionally, to avoid snails because of creeping out of the aquarium a net was used as cover. Afterwards, five snails after adaption (see above) were transferred to each aquarium. At every sampling, all $L$. stagnalis from each aquarium were transferred to a petri dish with a tweezer and filled with methanol (VWR, Germany), to kill the snails. Thereafter, the whole water phase was removed as described above. The shell of each individual organism was removed from the tissue with a tweezer and placed on a petri dish. Subsequently, both (shell and tissue) were dried separately for $24 \mathrm{~h}$ at $100^{\circ} \mathrm{C}$ in a drying cabinet (Memmert, DE) and weighed afterwards (analytical balance, Sartorius MC1 AC210S). The tissue and the shell were crushed in a glass mortar grinder separately. The dried material was transferred into LSC vials and filled up with LSC cocktail in a ratio of 1:1. In the following steps, the shells and the tissues were measured separately for each snail with LSC. Moreover, residuals like cellulose cloth imbued with methanol (VWR, Germany) and Pasteur pipette were measured (described above) by means of LSC as well. Additionally, all excrements of $L$. stagnalis were investigated. For this, all excrements from each aquarium were collected from the bottom of each aquaria, transferred into vials, filled up with LSC cocktail (ratio 1:1) and measured by means of LSC. Furthermore, at sampling point of $72 \mathrm{~h}$, the net potentially contaminated with radioactivity was added to the residuals. For this, the cellulose cloth was used to absorb the radioactivity from the net. Equally, a recovery rate was also calculated for all sampling points together with the water phase, tissue, shell, excrements and residuals. Moreover, a bioconcentration factor (BCF) was calculated using the following equation (Eq. 2):BCF $=\mathrm{c}$ (snailtissue)/c(water) [L/kg]

Effect studies. TEM and SEM investigation of MWCNTs, wMWCNTs and benthic biofilm. TEM (Libra120, Carl Zeiss Microscopy GmbH, Oberkochen, Germany) operated at $120 \mathrm{kV}$ acceleration voltage and SEM (NEON40, Carl Zeiss Microscopy $\mathrm{GmbH}$, Oberkochen, Germany) prosecuted at $3 \mathrm{kV}$ acceleration voltage, were used for a structure analyzes of the stock solution of MWCNTs and wMWCNTs. For TEM of MWCNTs in water, two microliters of liquid were dropped on plasma-hydrophilized TEM grids and dried at room temperature. For SEM of MWCNTs in water, five microliters of liquid were dropped on plasmahydrophilized $5 \mathrm{~mm} \times 5 \mathrm{~mm}$ silicon wafers and dried at room temperature. The Silicon wafers were mounted with double-sided conductive tape on SEM sample stamps. To investigate the impact of wMWCNTs on biofilm structure, an exposure approach with $0.1 \mathrm{mg} / \mathrm{L}$ wMWCNTs was performed. The biofilm was sampled from Gauernitzbach and allowed to grow on glass slides for one week in an analogous manner as described above added with $0.1 \mathrm{mg} / \mathrm{L}$ wMWCNTs. For SEM of the biofilm, small pieces of biofilm-coated glass slides were broken off and mounted with double-sided conductive tape on SEM sample stamps. All samples were coated with $20 \mathrm{~nm}$ carbon (SCD500 coater, Leica Microsystems $\mathrm{GmbH}$, Germany) to reduce charging under the electron beam.

Visual examination of L. stagnalis. To get a conception how L. stagnalis was affected by wMWCNTs, a prior test with benthic biofilm contaminated wMWCNTs $(10 \mathrm{mg} / \mathrm{L})$ was investigated visually. For this, $L$. stagnalis was grazed over $7 \mathrm{~d}$ on it and analyzed afterwards. The shell was removed manually after freeze-drying (lyophilization, Shimadzu Emit, Christ GDH-60, serial: 603876). Further, the snails were imaged on a petri dish using a LED lamp as light source. 
Analysis of physiological markers. The supernatant of prior bonded biofilm (described above) was removed with a custom-made glass U-tube. For two replicates of the exposure, $10 \mathrm{mg}$ of wMWCNTs were weighed with a micro balance (analytical balance, Sartorius) and dispersed for 30 min among a continuous sonication (Bandelin Sonopuls GM 70, MS 72/0, P 60 W) in a beaker which contained 1L of modified Borgmann medium. The dispersion was always recreated adequate for two replicates.

Afterwards, $500 \mathrm{~mL}$ of the dispersion was added carefully poured along the aquarium glass wall to each aquarium with bonded biofilm and also $500 \mathrm{~mL}$ of pure Borgmann medium was added to each control aquaria. The remaining dispersion in the beaker was sonicated again for $10 \mathrm{~min}$ to avoid agglomeration until it was exhausted. Following, five snails were put into each aquarium after adaption (see above) and equipped with a glass covering to avoid the creeping out. All aquaria were continuously renewed every three days during the whole effect study. Thereby, the snails were taken out of each aquarium and stored for a short time into a petri dish which was filled with Borgmann medium. After purification, the snails were returned into the new aquaria which were previously inhered each with benthic biofilm for $24 \mathrm{~h}$. After $24 \mathrm{~d}$, no wMWCNT was added to the exposure aquaria and everything was renewed with pure Borgmann medium. Samples of $L$. stagnalis were randomly taken out and investigated after $24 \mathrm{~d}$ and additionally after $28 \mathrm{~d}$ of depuration.

As physiological markers the concentration of glycogen, TGs and the ratio of RNA/DNA were investigated at the University of Koblenz-Landau. Four replicates from each sampling point, consisting of three snails respectively (pooled), were used for each physiological marker analysis. The shells of each individual were removed and all samples were freeze-dried for $24 \mathrm{~h}$ (Shimadzu Emit, Christ GDH-60, serial: 603876). Afterwards the samples were stored in a desiccator until use. For each analysis, 2-3 mg of dried biomass of $L$. stagnalis were transferred into a pre-weighted $1.5 \mathrm{ml}$ Eppendorf tube containing four glass beads. The weight was determinded with a micro balance. Afterwards the samples were homogenized in a bead mill (Retsch 40MM, Hahn, Germany) for 3 min at $25 \mathrm{~Hz}$. The glycogen concentration was determined according to Koop et al. (2011). The extraction and quantification of TGs were conducted using the commercial TG assay DiaSys Diagnostic 2015 (Hoppeler et al. 2018). The RNA/DNA ratio was quantified via fluorometer (Qubit ${ }^{\circledR}$ 2.0 Fluorometer, Thermofisher, Waltham, USA) with the commercial assay MasterPureTM Complete RNA and DNA Purification (Epicentre, Madison, USA). For the extraction of nucleic acids $1 \mathrm{mg}$ dry tissue was homogenized in a bead mill by adding $300 \mu \mathrm{L}$ lysis buffer $(1 \mu \mathrm{L}$ proteinase $\mathrm{K}, 300 \mu \mathrm{l}$ Tissue and cell lysis solution) and incubated for $15 \mathrm{~min}$ at $65^{\circ} \mathrm{C}$ in a thermomixer with $1200 \mathrm{rpm}$ (Eppendorf Thermomixer comfort, Wesseking, Berzdorf, Germany). Subsequently, $150 \mu \mathrm{L}$ of protein precipitation agent was added to each sample, which was then vortexed and centrifuged at $4^{\circ} \mathrm{C}$ and $18,000 \mathrm{~g}$ for $10 \mathrm{~min}$. After transferring the supernatant into RNase- and DNase-free Eppendorf tubes, $500 \mu \mathrm{l}$ isopropanol was added which induced the precipitation of RNA/DNA. To facilitate precipitation, the samples were inverted several times and centrifuged at $4^{\circ} \mathrm{C}$ and $18,000 \mathrm{~g}$ for $10 \mathrm{~min}$. The pellet was rinsed twice with $70 \%$ ethanol and resolved in $50 \mu \mathrm{L}$ TE-buffer. The concentration of RNA and DNA was measured with a Plate Reader (EnSpire Multimode Plate Reader, Perkin Elmer, Germany) using the QubitTM dsDNA BR Assay Kit and QubitTM RNA BR Assay Kit (Invitrogen ${ }^{T M}$, Life Technologies ${ }^{T M}$, Darmstadt, Germany). For the calculation of the lipid concentration in dry weight per pooled sample, the 
molar weight of the most common fatty acid in aquatic invertebrates, linoleic acid, was used (Arakelova et al. 2009). All the samples were determined in dry weight. For consideration in wet weight, a factor of 4.5 should be taken into account (Worischka et. al. 2014).

Histology and Electron Microscopy. For histology, samples of L. stagnalis were examined after $10 \mathrm{~d}$ of exposure. The intestinal tract of $L$. stagnalis and the investigated parts were highlighted in grey (Fig. 2, points VII- XI). Two of the five snails of control and exposition animals were used for histology investigations. For histology and EM, whole snails were sedated in $1 \%$ of hydroxylamine solution, followed by removal of the shell and fixation in $4 \%$ formaldehyde in $100 \mathrm{mM}$ phosphate buffer. The dissected tissue from the digestive tract were postfixed in modified Karnovsky fixative (Karnovsky 1965, $2 \%$ glutaraldehyde, $2 \%$ formaldehyde prepared from PFA prills, $2 \mathrm{mM}$ calcium chloride in $150 \mathrm{mM}$ cacodylate buffer). After washing in cacodylate buffer and phosphate-buffered saline (PBS), the samples were decalcified in $20 \%$ aqueous EDTA (Osteosoft, Merck) for several hours at $37^{\circ} \mathrm{C}$, followed by washing in PBS and water. For histology, the samples were dehydrated in a graded series of ethanol/water mixtures $(30 \%, 50 \%, 70 \%, 90 \%, 96 \%)$ up to $100 \%$ ethanol $(2 \times)$ and infiltrated and embedded into the methacrylate resin Technovit 7100 (Heraeus Kulzer, see Kurth et al. 2012). $2 \mu \mathrm{m}$ thin sections were stained with toluidine blue/borax and analyzed with a Keyence Biozero 8000 light microscope. For SEM, the decalcified samples were postfixed with $1 \%$ osmium tetroxide, dehydrated in a graded series of ethanol (30\%, 50\%, 70\%, 90\%, 96\%, 3× 100\% ethanol, pure ethanol on molecular sieve) and critical point dried using the Leica CPD300 dryer (Leica Microsystems, Vienna, Austria). Dried samples were mounted on a $12 \mathrm{~mm}$ aluminium stub coated with a conductive carbon pad and sputter coated with gold using the Baltec SCD 050 sputter coater (thickness $15 \mathrm{~nm}$ ). Finally, the samples were analyzed with a Jeol JSM7500F cold field-emission scanning electron microscope (Jeol, Freising, Germany) at $5 \mathrm{kV}$ acceleration voltage (working distance $8 \mathrm{~mm}$, lower secondary electron detector). For TEM, the sample were postfixed and contrasted in $2 \%$ aqueous $\mathrm{OsO}_{4}$ solution containing $1.5 \%$ potassium ferrocyanide and $2 \mathrm{mM} \mathrm{CaCl}_{2}$ for 30 min on ice. After washing in water, the samples were incubated in $1 \%$ thiocarbohydrazide in water ( $20 \mathrm{~min}$ at room temperature), followed by washing in water and a second osmium contrasting step in $2 \% \mathrm{OsO}_{4} /$ water (30 min, on ice). Samples were washed in water and bloc contrasted with $1 \%$ uranyl acetate/water on ice overnight. Afterwards it was washed again in water, dehydrated in a graded series of ethanol/water $(30 \%, 50 \%, 70 \%, 90 \%, 96 \%, 3 \times 100 \%$ ethanol (pure ethanol on molecular sieve), and infiltrated in the epoxy resin EMbed 812 (epoxy/ethanol mixtures: 1:3, 1:1, 3:1 for $1 \mathrm{~h}$ each, pure epon (epoxy resin) overnight, pure epon $5 \mathrm{~h}$ ). Finally, the samples were embedded in flat embedding molds and cured at $60^{\circ} \mathrm{C}$ overnight. After polymerisation, the tissue was cut into semi-thin sections of $1 \mu \mathrm{m}$ with a glass knife using the Leica UC6 ultramicrotome (Leica Microsystems, Wetzlar, Germany). The sections were stained with $1 \%$ toluidine blue and $0.5 \%$ borax to evaluate the tissue quality and select areas of interest. Afterwards ultrathin sections $(70 \mathrm{~nm})$ were prepared, collected on formvarcoated slot grids, and stained with lead citrate (Venable and Coggeshall 1965) and 4\% uranyl acetate. Contrasted ultrathin sections were analyzed on a FEI Morgagni D268 (FEl, Eindhoven, The Netherlands, camera: MegaView III, Olympus) or a Jeol JEM1400 Plus (JEOL, Garching, Germany, camera: Ruby, JEOL) both at $80 \mathrm{kV}$ acceleration voltage. 
Statistics. Data analysis was performed with software R (RStudio Team 2017). The statistical test is a Wilcoxon Sign Rank test, which is applicable for outlier analysis and thus resistant to aberrations. This nonparametric test was used because of the small sample size. The significance level was $p \leq 0.05$ with the corresponding W-value (test statistic). A decrease in the concentrations of the physiological marker was expected in the experiment. Therefore, a one-sided test was applied. For the controls, however, no direction was expected. Hence, a two-sided test was realized.

\section{Results}

Quantification study. Quantification on ${ }^{14} \mathrm{C}$-wMWCNT uptake in benthic biofilm and L. stagnalis. For all control samples concerning benthic biofilm and $L$. stagnalis, no radioactivity was detected. The distribution of radiolabeled ${ }^{14} \mathrm{C}$-wMWCNTs between water and biofilm was investigated (Fig. 3, left). The radioactivity decreased in the water phase over time. From the beginning of the experiment with $100 \%$ (t0), equal to a concentration of $0.1 \mathrm{mg}$ wMWCNT per liter, the amounts declined to a value of $62.8 \pm 4.5 \%$ $(4 \mathrm{~h})$ in the water phase. Afterwards, $4.8 \pm 1.3 \%(24 \mathrm{~h}), 1.28 \pm 0.04 \%(120 \mathrm{~h})$, and $1.72 \pm 1.1 \%(168 \mathrm{~h})$ of applied radioactivity (AR) was found in the water phase. Thus, a noticeable decrease in ${ }^{14} \mathrm{C}$-wMWCNT concentration was recorded while the radioactivity in the benthic biofilm increased from $14.7 \pm 1.6 \%(4 \mathrm{~h}$ ) to $35.9 \pm 2.8 \%$ ( $24 \mathrm{~h}$ ), $42.4 \pm 4.7 \%$ (120 h) and $45.9 \pm 6.5 \%$ (168 h) (Fig. 3, left). The residuals as mentioned above amounted to $7.4 \pm 2.4 \%(4 \mathrm{~h}), 13.2 \pm 2.1 \%(24 \mathrm{~h}), 11.6 \pm 2.2 \%(120 \mathrm{~h})$ and $12.5 \pm 1.4 \%$ of AR at the end of the experiment. The recovery rate of ${ }^{14} \mathrm{C}$-wMWCNTs for each sampling point is the sum of the relative amount of water phase, biofilm and residuals. Consequently, the recovery declined from 85 $\pm 2.4 \%$ ( $4 \mathrm{~h}$ ) to $60.2 \pm 5.3 \%$ (168 h), i.e., a loss of approximately $40 \%$ of AR was found at the end of the experiment. The maximum uptake of ${ }^{14} \mathrm{C}$-WMWCNT in benthic biofilm was reached after day five and amounted to $529 \mu \mathrm{g}$ wMWCNT/g dry weight (Fig. 3, right). Afterwards the value decreased slightly to 465 $\mu \mathrm{g}$ wMWCNT/g dry weight at day seven. No BCF was calculated for benthic biofilm because no separation of wMWCNTs from the complex biofilm suspension was possible.

Relative amounts of ${ }^{14} \mathrm{C}$-wMWCNTs in snail tissue ranged from $1.9 \pm 0.8 \%(4 \mathrm{~h}), 4.8 \pm 2.4 \%(24 \mathrm{~h}), 5.0 \pm$ $0.6 \%$ (48 h) to $1.6 \pm 1.1 \%$ (72 h) (Fig. 4, left). Additionally, ${ }^{14} \mathrm{C}$-wMWCNTs for the snail shell was found with results of $2.0 \pm 0.7 \%(4 \mathrm{~h}), 2.4 \pm 0.4 \%(24 \mathrm{~h}), 2.7 \pm 2.2 \%(48 \mathrm{~h})$ and $0.8 \pm 0.5 \%(72 \mathrm{~h})$. The excrements showed a percentage radioactivity of $0.9 \pm 0.4 \%(4 \mathrm{~h}), 2.0 \pm 1.0 \%(24 \mathrm{~h}), 1.8 \pm 1.0 \%(48 \mathrm{~h})$ and $1.7 \pm 1.1 \%$ (72 h). A same course for the parts of snail tissue, snail shell and excrements of $L$. stagnalis is discernible. The residuals that included the cellulose cloth and Pasteur pipettes feature values of $35.4 \pm$ $2.0 \%(4 \mathrm{~h}), 42.7 \pm 2.7 \%(24 \mathrm{~h}$ ) and $33.3 \pm 2.2 \%$ ( $48 \mathrm{~h}$ ). At $72 \mathrm{~h}$, the cover net of the aquaria was added to the whole residual phase and thus a higher radioactivity than for the other sampling points was analyzed $(47.0 \pm 3.5 \%)$. The recovery again was low ranging from $82 \pm 4.2 \%(4 \mathrm{~h})$ to $60.2 \pm 5.3 \%(72 \mathrm{~h})$. The enrichment of ${ }^{14} \mathrm{C}$-wMWCNT in L. stagnalis shows a maximum of $79.6 \pm 34.7 \mu \mathrm{g} w M W C N T / \mathrm{g}$ dry weight at $24 \mathrm{~h}$ (Fig. 4, right) but decreased to $20,65 \pm 12.50 \mu \mathrm{g}$ wMWCNT/g dry weight (72 h). Considering the large scatter of data with standard deviations at $48 \mathrm{~h}$ and $72 \mathrm{~h}$ of $9.4 \%$ and $9.0 \%$, the accumulation of

${ }^{14} \mathrm{C}$-wMWCNTs in L. stagnalis could have reached steady state. ${ }^{14} \mathrm{C}$-wMWCNTs continuously accumulate 
in the benthic biofilm after more than $24 \mathrm{~h}$ (Fig. 3, right), whereas a steady state of ${ }^{14} \mathrm{C}$-wMWCNTs uptake in L. stagnalis was achieved at $24 \mathrm{~h}$ (Fig. 4, right).

The relative distribution of ${ }^{14} \mathrm{C}$-wMWCNTs in L. stagnalis (Fig. 4, left) shows a decrease of ${ }^{14} \mathrm{C}$-wMWCNTs in the water phase over time. The amounts of ${ }^{14} \mathrm{C}$-wMWCNTs in the water phase ranged from $41.8 \pm 9.4 \%$ (4h), $23.3 \pm 15.2 \%$ ( $24 \mathrm{~h}$ ), $31.1 \pm 12.5 \%$ (48 h) to $12.4 \pm 3.0 \%$ (72 h).

Due to the steady state in L. stagnalis, a BCF of 3,500 L/kg in tissue was ascertained and the results of all BCFs in tissue dry weight per time points are shown in Table 2.

Table 2

The bioconcentration factor [L/kg] and log (BCF) of ${ }^{14} \mathrm{C}$-wMWCNTs over time in tissue of L. stagnalis are presented.

\begin{tabular}{|lll|}
\hline Time & BCF tissue dry weight & Log (BCF) \\
\hline $4 \mathrm{~h}$ & 510 & 2.7 \\
\hline $24 \mathrm{~h}$ & 3,481 & 3.5 \\
\hline $48 \mathrm{~h}$ & 2,254 & 3.4 \\
\hline $72 \mathrm{~h}$ & 1,452 & 3.2 \\
\hline
\end{tabular}

Effect study. TEM and SEM investigation of MWCNTs, wMWCNTs and benthic biofilm. Structural insights by electron microscopy (TEM, SEM) of wMWCNTs, MWCNTs, biofilm and extracellular polymeric substances (EPS) are given in Fig. 5. Figure 5a and 5b show the wMWCNTs and MWCNTs in TEM, Fig. 5c and 5d in SEM. The structures of WMWCNTs and MWCNTs for TEM are similar and look like helices with irregularities in their form. The SEM images feature a complex entangled structure of both (Fig. 5c, d). No structural differences are visible. Biofilm exposed one week to wMWCNTs and was imaged with SEM (Figure, $5 \mathrm{e}-\mathrm{g}$ ). Figure $5 \mathrm{e}$ reveal an interaction between diatoms among themselves without wMWCNT (Fig. 5e, arrows). After exposure to wMWCNTs, a more complex network is apparent and in some areas a network between extracellular polymeric substances (EPS) of some broken diatoms and wMWCNTs was observed, too (Fig. 5, f-g, arrows). It seems to be a conjunction between diatom cells and their EPS together with wMWCNTs (Fig. 5, f-g).

Visual examination of $L$. stagnalis. To demonstrate the accumulation of WMWCNTs by L. stagnalis, the individuals were dissected from their shells and imaged (Fig. 6, a-c). The control sample with shell (Fig. 6a) exhibit a brown hue. The contaminated samples (Fig. 6, b-c) illustrate strong grey staining from the head up to the intestine. It is discernible that the intestine is completely black (Fig. 6b). The example in Fig. $6 \mathrm{c}$ shows a black midintestine. In contrast to this, no grey tinge of these parts was detected in the control individuals, rather the whole body appears tanned (Fig. 6a).

Analysis of physiological markers. The concentrations of the physiological marker glycogen and TGs as well as RNA/DNA ratios in the control and exposed snails were investigated (Fig. 7-9). In the following, 
the time point ' $24 \mathrm{dEx}$ ' denotes the measured quantity after $24 \mathrm{~d}$ of exposure and ' $+28 \mathrm{dDe}$ ' corresponds to the treatment where the formerly exposed snails have undergone a depuration phase of $28 \mathrm{~d}$ afterwards. For comparison, untreated animals were examined as a control group also after $24 \mathrm{~d}$ ('24dCo') and $24+$ $28=52 \mathrm{~d}($ ('52dCo'). For glycogen (Fig. 7), the control shows a significant increase over time between t24dCo (mean: $31.43 \mu \mathrm{mol} / \mathrm{g}$ dry weight) and t52dCo (mean:109.64 $\mu \mathrm{mol} / \mathrm{g}$ dry weight, Table 3). However, after t24dEx the median value did not differ significantly from the control t24dCo (Table 3). No significant difference was found at the end of the experiment between the control t52dCo and the exposure approach past depuration $+\mathrm{t} 28 \mathrm{dDe}$ with a mean of $93.31 \mu \mathrm{mol} / \mathrm{g}$ dry weight.

The TGs and lipid concentrations were similar over the experimental duration in the controls (mean of t24dCo: $5.21 \mu \mathrm{mol} / \mathrm{g}$ and $1.46 \mathrm{mg} / \mathrm{g}$ dry weight of lipid concentration; mean of t52dCo: $4.83 \mu \mathrm{mol} / \mathrm{g}$ and 1.35 dry weight of lipid concentration, Table 3, Fig. 8). The control t24dCo compared to the exposure t24dEx (Fig. 8) feature no significant differences between them but it can be interpreted as weakly significant within a significance level of $10 \%$ (Table 3 ). Among t52dCo and $+\mathrm{t} 28 \mathrm{dDe}$ no significances in TGs concentration are analyzed (Table 3). After the depuration, $1.45 \mathrm{mg} / \mathrm{g}$ dry weight and thus a similar value to both controls (t24dCo and $\mathrm{t} 52 \mathrm{dCo}$ ) was calculated for the lipid concentration.

In RNA/DNA analyzes, there was no difference between the controls over time (mean of t24dCo: 5.1, mean of t52dCo: 4.9). Whereas the ratio was significantly reduced in t24dEx (mean 2.8) compared to t24dCo (Table 3, Fig. 9). After $+\mathrm{t} 28 \mathrm{dDe}$, the previously exposed animals reached the same level of RNA/DNA ratio as the group of animals that had never been subjected to wMWCNTs (mean 4.4 and 4.9, Table 3, Fig. 9).

Table 3

Statistical analyzes of the quantitative values for glycogen, TGs and RNA/DNA among different time points and the corresponding $\mathrm{W}$ and $p$-values are shown.

\begin{tabular}{|llll|}
\hline W and $p$-values & glycogen & TGs & RNA/DNA \\
\hline $\mathrm{W}(\mathrm{t} 24 \mathrm{dCo} / \mathrm{t} 52 \mathrm{dCo})$ & 0 & 10 & 5 \\
$p(\mathrm{t} 24 \mathrm{dCo} / \mathrm{t} 52 \mathrm{dCo})$ & 0.03 & 0.69 & 0.49 \\
$\mathrm{~W}(\mathrm{t} 24 \mathrm{dCo} / \mathrm{t} 24 \mathrm{dEx})$ & 4 & 13 & 16 \\
$p(\mathrm{t} 24 \mathrm{dCo} / \mathrm{t} 24 \mathrm{dEx})$ & 0.9 & 0.10 & 0.01 \\
$\mathrm{~W}(\mathrm{t} 52 \mathrm{dCo} /+\mathrm{t} 28 \mathrm{dDE})$ & 10 & 7 & 11 \\
$p(\mathrm{t} 52 \mathrm{dCo} /+\mathrm{t} 28 \mathrm{dDE})$ & 0.34 & 0.66 & 0.24 \\
\hline
\end{tabular}

Histology and Electron Microscopy of snail intestine. To further understand the impact of the wMWCNTs on the snails, we took a closer look to potential contact areas between the snail body and the wMWCNTs (cnts), focusing on the intestinal tract. The wMWCNTs are ingested together with the biofilm, and histology of whole snails demonstrated them in the lumen of the complete intestinal tract (e.g., in the 
oesophagus, stomach, and different parts of the intestine, Fig. 10). wMWCNTs are recognizable as black accumulated material in the lumen of the digestive tract (Fig. 10a, b). To further characterize the accumulated wMWCNTs, we dissected pieces of the intestine (Fig. 2, regions VII-XI) and processed them for electron microscopy. The tissue was either embedded in epon and ultrathin sections were prepared for TEM (Fig. 10, c-e), or they were dehydrated and critical-point dried for SEM (Fig. 10, f-h). The wMWCNTs can be identified as thick bundles (indicated by the dashed green lines in Figs. 10c and d), that are found together with bacteria and algae in the intestinal lumen, close to the apical microvilli of the enterocytes (Fig. 10, d). At higher magnifications, the wMWCNTs appear as sharply outlined tubes with open ends (Fig. 10, e). Their characteristics are the unique shape and refracting properties, allowing a differentiation between wMWCNTs and other organic structures, such as membrane fractions (see Fig. 10, e). In the SEM the content of the intestine shows a typical biofilm composition including diatoms and bacteria (Fig. 10, $\mathrm{f}, \mathrm{g}$ ). The wMWCNTs again are apparent as bundles of fibrous material (indicated by the green dashed line in Fig. 10, g) equivalent to what is obvious in TEM images. At higher magnification MWCNT can be distinguished by their typical structure (compare Fig. 10, h to Fig. 5, a). Closer inspection of the enterocytes, however, revealed no intracellular wMWCNTs (images not shown). Uptake of the wMWCNTs occurs only in the digestive glands (not shown).

\section{Discussion}

We investigated the impacts of wMWCNTs on single species, communities and trophic interactions in the aquatic ecosystem addressing multiple endpoints. To our knowledge, no comparable data is available for experiments with ${ }^{14} \mathrm{C}$-wMWCNTs or for histology in L. stagnalis. Because of the high variety of concentrations of CNTs generally occurring in the environment, we used different concentrations in our experiments to cover various scenarios. Therefore, $0.1 \mathrm{mg} / \mathrm{L}{ }^{14} \mathrm{C}$-wMWCNTs was applied in our quantification study and $10 \mathrm{mg} / \mathrm{L}$ in the effect studies.

\section{Experimental set-up of the workflow}

First of all, the survival, development and response of control organisms met the validity criteria in accordance with the OECD (2016) guideline No. 243.

The oxygen content was $>60 \%$ in the effect study and the temperature was held constantly during both the quantification- and effect study. In summary, the results of the effect study show no impairments in both control groups (t24Co and t52dCo) due to the experimental set-up.

The benthic biofilm is a complex community of microorganisms, algae (e.g., diatoms, cyanobacteria and green algae), ciliates and flagellates. We were able to show interacting diatoms and detected no obvious damages of species in the absence of wMWCNTs. Furthermore, no mortality in the control groups as well as for WMWCNTs exposed individuals of $L$. stagnalis, were demonstrated in all studies. The controls for TGs and RNA/DNA reveal a good survival rate and the individuals fared well. Eminently, the increase of the glycogen content in the controls shows adaptation to the given system. Consequently, conformity 
among the different controls means no impairments by the experimental test conditions including the used Borgmann medium.

\section{Quantification of uptake and elimination of ${ }^{14} \mathrm{C}-$ wMWCNTs in benthic biofilm and $L$. stagnalis}

Using radioactive labeling, we were able to show that wMWCNTs at $0.1 \mathrm{mg} / \mathrm{L}$ accumulate in benthic biofilm. The enrichment of $529.0 \mu \mathrm{g}{ }^{14} \mathrm{C}$-wMWCNTs/g dry weight in biofilm is significantly higher than that for $L$. stagnalis with a value of $79.6 \mu \mathrm{g}{ }^{14} \mathrm{C}$-wMWCNTs/g dry weight. The biofilm as a "surfacecovering" layer in the aquarium offers a large surface area for the accumulation of wMWCNTs acting as a sink. Calculating a BCF for benthic biofilm is difficult due to its composition of diverse organisms. Bjorkland, Tobias and Petersen (2017) provided a tabular overview of different BCF for single primary producers and ${ }^{14} \mathrm{C}-\mathrm{MWCNT}$. For example, the algae Desmodesmus subspicatus (D. subspicatus) was exposed to $1 \mathrm{mg} / \mathrm{L}{ }^{14} \mathrm{C}-\mathrm{MWCNTs}$ for $72 \mathrm{~h}$. A BCF of 5,000 L/kg was determined (Rhiem et al. 2015). For the ciliate Tetrahymena thermophila exposed to $0.3 \mathrm{mg} / \mathrm{L}$ acid-purified ${ }^{14} \mathrm{C}-\mathrm{MWCNTs}$ for $22 \mathrm{~h}$, a BCF of $2900 \pm 800 \mathrm{~L} / \mathrm{kg}$ was calculated (Mortimer et al. 2016). However, these factors were obtained in experiments with single species. In contrast, the biofilm community comprised a complex system of different groups of organisms. Differentiation of the radiolabeled wMWCNTs in the various fractions of the biofilm is not possible, thus, we did not calculate a BCF.

For L. stagnalis, a BCF of 3,500 L/kg was ascertained in our quantification study. Petersen et al. (2009) calculated normalized body burden values of 440,000 $\pm 190,000$ (equivalent to BCF) for Daphnia magna during $48 \mathrm{~h}$ with $0.1 \mathrm{mg} / \mathrm{L}$ acid-oxidized ${ }^{14} \mathrm{C}-\mathrm{MWCNT}$ dispersed in water. Bjorkland, Tobias and Petersen (2017) reported in their summary a BCF of $73 \mathrm{~L} / \mathrm{kg}$ after $7 \mathrm{~d}$ exposure to $1 \mathrm{mg} / \mathrm{L}$ acid-purified ${ }^{14} \mathrm{C}$ MWCNTs to Danio rerio (Maes et al. 2014a). For comparison, D. magna is a Crustacean and able to breathe through the surface of their turgor extremities and through their entire body surface. Thus, the high BCF of daphnids could be explained in comparison to our results and to the results of Maes et al. (2014a). These different bioaccumulation factors are attributed to the different ingestion routes and sizes of the respective organisms, but also due to the chemical structures of the test substances. Lalah et al. (2003) exposed L. stagnalis to ${ }^{14} \mathrm{C}$-p-nonylphenol. They observed the highest BAF (described as it refers to BCF) of $242 \mathrm{~L} / \mathrm{kg}$ after three $\mathrm{d}$ of exposure. Although a comparison of non-soluble nanomaterial and a dissolved organic compound regarding uptake is difficult, it reflects the accumulation potential of the snails.

In general, to investigate a BCF in a test system with L. stagnalis and wMWCNTs is difficult because the snails continuously move all over the aquarium and can accumulate via water and via food. The radioactivity in the water phase decreased rapidly due to sedimentation and agglomeration of the nanotubes. Concomitantly, the recovery of radioactivity decreased up to a loss of ca. $40 \%$. We speculate, that due to the large size of the aquarium in our experiments the high affinity of the nanotubes to adsorb to surfaces like the glass walls, sealings etc., some radioactivity could not be recovered. Petersen et al. (2009) explained a low recovery of about $60 \%$ in his experiments assuming a similar reason. 


\section{Glycogen, triglycerides and RNA/DNA ratio as physiological markers in L. stagnalis}

We showed that wMWCNTs certainly have an influence on anabolic processes, most likely somatic growth, because the RNA/ DNA ratio was significantly reduced upon exposure to wMWCNTs. It is a common hypothesis that the RNA/DNA ratio increases during periods of high metabolic activity and decreases in the case of growth inhibition. High metabolic activities might occur during moderate stress situations. Consequently, organisms have high maintenance costs due to the compensatory upregulation of the detoxification and cell protection mechanisms (Sokolova et al. 2012). The RNA/DNA ratio provides information about the actual investment and the associated anabolic activity of organisms. Elser et al. (2005) found a RNA/DNA ratio of 4.3 in their control snails (Mexithauma quadripaludium) in a study on the response to phosphorus enrichment by modern stromatolitic microbial communities. Our results showed similar RNA/DNA ratios for the controls.

The ratio has often been used as an indicator of the nutritional status of fish larvae and larval growth (Buckley 1984, Peck et al. 2003). This statement is supported by the observation that the ratio in our experiments increases again after depuration. Thus, it indicates some toxic stress for the organisms after exposure, but they seem to partially recover.

The analysis of physiological markers such as the glycogen and TGs are suitable tools to investigate environmental impacts on animals (Koop et al. 2008; Zubrod et al. 2011). Storage of energy invoked when the energy intake exceeds the current energy requirement and it enables to survive periods of food shortage. In addition, stressors such as chemical pollutants can cause higher energy demands and thus lead to changes in the energy metabolism. Decreased energy stores might be interpreted as an indicator of moderate physiological stress (Sokolova et al. 2012). Alterations in the energy budgets can lead to changes in macronutrient contents (Nisbet et al. 2012; Fidder et al. 2016). In our experiments, exposure to wMWCNTs did not significantly change the glycogen concentration. Mohamed and Geraerts (1976) reported a degradation of glycogen during the transition from aerobiosis to anaerobiosis. In the absence of food, they detected $86.4 \mu \mathrm{mol} / \mathrm{g}$ wet weight $(19.2 \mu \mathrm{mol} / \mathrm{g}$ dry weight) of glycogen after $24 \mathrm{~h}$ in control individuals. Changing from aerobic to anaerobic conditions after $15 \mathrm{~h}$, the glycogen level dropped to 71.4 $\mu \mathrm{mol} / \mathrm{g}$ wet weight $(15.9 \mu \mathrm{mol} / \mathrm{g}$ dry weight $)$ and $59.5 \mu \mathrm{mol} / \mathrm{g}$ wet weight $(13.2 \mu \mathrm{mol} / \mathrm{g}$ dry weight). The glycogen concentrations in our control groups were between $15.8-48.9 \mu \mathrm{mol} / \mathrm{g}$ dry weight at $24 \mathrm{~d}$ and increased at $52 \mathrm{~d}(87.6-140.3 \mu \mathrm{mol} / \mathrm{g}$ dry weight). The reason for that could be increased glucose storage (Melendez, Melendez-Hevia and Cascante 1997) representing a snapshot of the energy level. A further reason for the increased glycogen concentration could be the different developmental stage of the individual investigated at that day.

The TG level is considered to reflect the long-term status. McCauley et al. (1990) described the lipid concentration as an indicator of toxicant effects and/or organismal performance. Reategui-Zirena and Salice (2018) reported differences in the concentration of nutrients in the offspring of Lymnaea stagnalis affected by cadmium, pyraclostrobin and tributyltin. They measured among others the lipid concentration in egg masses and adult snails. They state that the lipids are suitable indicators for the nutritional state 
in cladocerans. For gastropods less data are available for comparison (Reategui-Zirena and Salice 2016). We calculated a lipid concentration of $0.15 \%$ dry weight in the controls and $0.08 \%$ in the exposure individuals at $24 \mathrm{~d}$. After the depuration, $0.14 \%$ was found in lipid concentration and thus similar to the control. Lalah et al. (2003) analyzed a lipid concentration of $4.4 \%$ wet weight ( $0.96 \%$ dry weight) after $3 \mathrm{~d}$ of exposure to ${ }^{14} \mathrm{C}$-p-nonylphenol isomer assuming a steady state of accumulation in $L$. stagnalis (size: $2.92-5.05 \mathrm{~cm}$ ). In our experiments, we noticed a decrease of TGs and lipid concentrations. Following the depuration, the mollusks were able to regain $98.9 \%$ of the lipid concentration and thus they recover their physiological state.

\section{Histological investigations}

Our histological analysis showed that wMWCNTs pass the digestive system and can be detected in the gut lumen as bundles. At $10 \mathrm{mg} / \mathrm{L}$, we found wMWCNTs in the lumen after $10 \mathrm{~d}$ of exposure. The WMWCNTs form black agglomerates in the digestive system after the uptake of wMWCNT contaminated biofilm. Jugdaohsingh et al. (1998) found a high affinity for polyhydroxy aluminium to mucus by grazing contaminated biofilm but it was also found in the digestive system of $L$. stagnalis. The wMWCNTs can be recognized as agglomerate piles located extracellularly in front of the microvilli of the enterocytes. After depuration, no wMWCNTs were found extracellularly in the digestive system. The wMWCNTs accumulate not just everywhere but mainly in the digestive tract. Clearly visible accumulated wMWCNTs are found in the midintestine. The quantification study gives a view of the ability to enrich the ${ }^{14} \mathrm{C}$-wMWCNTs in a moderate way, and microscopy reveals a semi-quantitative analysis of their local distribution. Amorim et al. (2019) feature a compilation of classical toxicological values and of bioaccumulation in L. stagnalis. They summarized previously published ecotoxicological tests with $L$. stagnalis. There are 28 publications concerning tissue analyzing of digestive glands as described in Elangovan et al. (1997), Coeurdassier et al. (2004), Dobranskyte et al. $(2004,2006)$ or, e. g., in Walton et al. (2009). Carriker and Bilstad (1946) disclosed the swallow of organic and inorganic materials in digestive cells in L. stagnalis. Further on, small and indigestible particles $(0.1-0.4 \mu \mathrm{m})$ can be incorporated into small, green and yellow granules, which are located in the digestive gland (Walker 1970). Elangovan et al. (2000) investigated the fate and localization of aluminium in the digestive gland of L. stagnalis. The electron microscopy showed different granule types. This reflects the digestive gland as a sink of accumulated aluminium. These granules are grain shaped storages in biological cells, which include storage substances like glycogen, lipid or protein. We did not detect intracellular wMWCNTs or unusual granules in intestinal epithelial cells (data not shown), but they may still be found in the cells of the digestive gland, which is currently under investigation. This will help to answer whether wMWCNTs are taken up intracellularly in granules, as described by Elangovan et al. (2000).

\section{Trophic transfer of wMWCNT}

An influence on benthic biofilm as the food source for lots of primary consumers, has been depicted in the EPS interaction with wMWCNTs by SEM. EPS provide a matrix for embedding microorganisms in the biofilm and are able to keep agglomerates in their three-dimensional arrangement (Schulte and Flemming 
2006). Even low concentrations of $0.1 \mathrm{mg} / \mathrm{L}$ wMWCNTs had an influence on the biofilm expressing a WMWCNT - EPS network and possible further growth inhibition. We found out that $L$. stagnalis was grazing the whole biofilm with its radula. Garacci et al. (2016) observed a similar network of graphene oxide layers and EPS of the freshwater diatom Nitzschia palea. In comparison to the experiment of Garacci et al. (2016), we obtained similar results of network formation already at a much lower concentration of $0.1 \mathrm{mg} / \mathrm{L}$ wMWCNTs after one week. In contrast, we investigated a natural biofilm composition and observed the nanotubes kind of amalgamated in this matrix. Thus, the probably is a transfer of wMWCNTs through the higher trophic levels.

Studies of Petersen et al. (2008) and Parks et al. (2013) displayed no negative effects on organisms exposed to nanoparticles (NP), whereas our results reveal obvious negative effects. Other studies with NP also revealed impacts on different organisms in vitro and in vivo (Werlin et al. 2011, Griffit et al. 2011). Werlin et al. (2011) investigated the effect of accumulated cadmium selenide quantum dots in Pseudomonas aeruginosa, when transferred into protozoa Tetrahymena thermophila. Afterwards the concentration of quantum dots in the predator T. thermophila was five times higher as for the bacterial loot. Thus, quantum dots can be bioavailable for higher trophic levels in the food chain. Griffit et al. (2011) investigated the chronic effects of silver nanoparticles (AgNP) to juvenile and adult sheepshead minnows Cyprinodon variegarus. Low amounts of AgNP showed a significant tissue burden for juveniles and adults which means a thickening of the tissue of epithelia gills.

Hudson et al. (2019) explained the trophic transfer of gold nano-particles to be organism specific in aquatic food webs. This was attributed to the unique feeding mechanisms of species. Balog et al. (2012) and Feiyue et al. (2004) qualified L. stagnalis as a more general feeder removing the complete periphyton matrix with its radula. In contrast, Hyalella azteca grazes rather selectively from the bottom side of the tiles where no periphyton had grown in the experiments (Hudson et al. 2019). In our workflow, the mollusks were found everywhere in the aquaria and not only on the bottom. Therefore, due to the grazing and feeding behavior we assess $L$. stagnalis as an important vector for a trophic transfer of wMWCNTs.

\section{Further research questions and risk assessment}

Although the primary consumer L. stagnalis was significantly influenced after the exposure to wMWCNTs, it fully recovered. No significant differences in physiological states were found after $28 \mathrm{~d}$ of depuration and no wMWCNTs were found in the gut after depuration. Enrichment in L. stagnalis decreased after $72 \mathrm{~h}$ to nearly the same level as observed after $4 \mathrm{~h}$. It would be important to know whether wMWCNTs might remain in the midintestine or digestive gland or whether some wMWCNTs are incorporated intracellularly in L. stagnalis and what effects would result from the incorporation. Anyhow, we clearly demonstrated the transmission of WMWCNT in the food chain.

The BCF of $3,500 \mathrm{~L} / \mathrm{kg}$ in L. stagnalis indicates a high bioaccumulation potential of the nanotubes resulting in the change of physiological biomarkers and thus stress for the organisms. Amorim et al. (2019) emphasized the importance of histological examinations for an ecotoxicological risk assessment. 
More information is necessary due to their widespread distribution and also further endpoints should be developed in addition to the previous knowledge in this field.

Selck et al. (2016) explained that many studies concerning nanomaterials were carried out for short-term exposures $(24-48 \mathrm{~h}$ ) with a lack of chronic and delayed effects to organisms. Beyond that, they highlighted the necessity to investigate modified nanomaterials together with long-term-experiments for a more comprehensive knowledge about fate, bioaccumulation and effects of nanomaterials to the environment. Consequently, we developed a workflow as short-term and long-term tests with quantitative and qualitative endpoints to support ecotoxicological risk assessment for weathered MWCNTs.

Regarding environmental risk assessment the production volume of 100 to 1000 t per year (Piccinno et al. 2012) is a relevant information. According to REACH chronic tests of substances and products are necessary if the production volume exceeds the threshold of 100 t per year (REACH Annex IX, 9.1.5; William, Berninger and Brooks 2011; Foth and Hayes 2008). Long et al. (2012) and Verneuil et al. (2015) investigated algae acute toxicity using $C$. vulgaris and determined an EC50 $(96 \mathrm{~h})$ of $41 \pm 3.0 \mathrm{mg} / \mathrm{L}$ and $N$. palea about $118 \mathrm{mg} / \mathrm{L}$ after $48 \mathrm{~h}$. For $D$. magna, an $E C 50_{(48 \mathrm{~h})}$ of $14 \pm 0.3 \mathrm{mg} / \mathrm{L}$ was investigated by Sanchis et al. (2016) due to the immobilization assay (OECD 202 and ISO 6341). Furthermore, a chronic test was performed with $D$. magna over $14 \mathrm{~d}$ and an EC50 of $4.3 \mathrm{mg} / \mathrm{L}$ was determined (Stanley et al. 2015). For $D$. rerio, a lowest observed effect concentration (LOEC) of $60 \mathrm{mg} / \mathrm{L}$ in embryos was found after 48 and $72 \mathrm{~h}$ (Asharani et al. 2008). Hence, D. magna is the most sensitive of these species with an effect concentration of $4.3 \mathrm{mg} / \mathrm{L}$. The availability of data comprising acute and one prolonged test results in an uncertainty factor of 100 and an extrapolated PNEC of $0.043 \mathrm{mg} / \mathrm{L}$.

Referring to our experiments the biofilm was affected at a water exposure concentration of $0.1 \mathrm{mg} / \mathrm{L}$, and the corresponding uncertainty factor results in 50; an additional chronic test is available. Thus, a lower PNEC of $0.002 \mathrm{mg} / \mathrm{L}$ is calculated. Estimating the MEC $(0.8 \mathrm{ng} / \mathrm{L}$, Maurer-Jones et al. 2013) to PNEC ratio, the risk quotient results in 0.0004 , i.e., well below 1 . Moreover, we can assess that the concentration of $529 \mathrm{mg} / 144 \mathrm{~cm}^{2}$ for benthic biofilm results in a risk quotient of 0.10 by using a MEC of $1 \mathrm{mg} / \mathrm{kg}$ in sediment (Selck et al. 2016). In our case, no risk was identified for water and sediment exposure, but a careful assumption leads to the conclusion that the risk quotient is getting a thousand times higher in sediment compartments.

\section{Conclusion}

Benthic biofilm as food source of $L$. stagnalis is a sink for wMWCNTs which form a dense network agglutinated by extracellular polymeric substances. Thus, wMWCNTs are transported via the food chain to the primary consumer $L$. stagnalis feeding on the biofilm conglomerate. Moreover, after ingestion the snails incorporate the nanotubes extracellularly in the gut lumen. The level of triglycerides in the snails responded to the exposure to the nanotubes and can serve as stress indicator, whereas the glycogen concentration was not significantly changed. Stress was also indicated by a significant inhibition of growth after $24 \mathrm{~d}$ of exposure with $10 \mathrm{mg} / \mathrm{L}$ wMWCNTs. Subsequent detailed histological analyzes 
showed that the mid gut gland, also referred to as hepatopancreas, may be a crucial compartment for the fate of wMWCNTs. The grazing behavior of the snails all over the aquaria render the quantification of WMWCNT uptake difficult. For this, a quantitative biomagnification study with radiolabeled ${ }^{14} \mathrm{C}$ WMWCNTs and with detailed histological studies of intestine and digestive gland, in particular the subcellular distribution of wMWCNTs, will be performed and reported separately.

\section{Declarations}

Ethics approval and consent to participate: Not applicable.

Consent for publication: Not applicable.

Availability of data and materials: On inquiry, the data presented in this study is available from the authors.

Competing interests: No conflicts of interest.

Funding: The research leading to these results received funding from Bundesministerium für Bildung und Forschung (BMBF) under Grant Agreement No 03XP0061B.

Authors' contributions: Conceptualization: Dirk Jungmann and Andreas Schäffer; Methodology: Katrin Weise, Thomas Kurth, Susanne Kretschmar; Software: Katrin Weise, Thomas Kurth; Validation: Katrin Weise, Irina Politowski, Thomas Kurth, Andreas Schäffer, Carola Winkelmann and Dirk Jungmann; Formal analysis: Thomas Kurth and Katrin Weise; Investigation: Katrin Weise, Irina Politowski, Susanne Kretschmar; Resources: Dirk Jungmann, Thomas Ulrich Berendonk, Andreas Schäffer, Carola Winkelmann; Data curation: Katrin Weise, Thomas Kurth, Irina Politowski, Carola Winkelmann; Writingoriginal draft: Katrin Weise; Writing-review \& editing: Thomas Kurth, Andreas Schäffer, Dirk Jungmann and Thomas Ulrich Berendonk; Visualization: Katrin Weise; Supervision: Dirk Jungmann; Project administration: Irina Politowski and Andreas Schäffer; Funding acquisition: Dirk Jungmann; All authors have read and agreed to the published version of the manuscript.

Acknowledgements. The authors would like to thank the Bundesministerium für Bildung und Forschung (BMBF) and 03XP0061B for funding the project NANO-Transfer. We thank the lead partner of Jülich for supporting the work during the project. Thomas Kurth and the EM-Facility are supported by the European Fund for Regional Development (EFRE). The authors acknowledge Petr Formánek of Leibniz-Institute for Polymer Research Dresden e.V. (IPF) for part of the presented TEM and SEM. Additionally, we thank Dirk Romeis from the IPF and Sandra Romeis for their statistical support.

\section{References}

1. Amorim J, Abreu I, Rodrigues P, Peixoto D, Pinheiro C, Saraiva A, Carvalho PA, Guimarães L, OlivaTeles $L$ (2019) Lymnaea stagnalis as a freshwater model invertebrate for ecotoxicological studies. 
Science of the Total Environment. 669:11-28. https://doi.org/10.1016/j.scitotenv.2019.03.035

2. Arakelova ES, Chebotareva MA, Zabelinskii S A, Ivanova VP (2009) Effect of Habitat and Motor Activity of Molluscs on Fatty Acid Composition of Triglycerides and Phospholipids. Journal of Evolutionary Biochemistry and Physiology 45:51-58. https://doi.org/10.1134/S0022093009010049

3. Asharani PV, Serina NGB, Nurmawati MH, Wu YL, Gong Z, Valiyaveettil S (2008) Impact of MultiWalled Carbon Nanotubes on Aquatic Species. Journal of Nanoscience and Technology 8:36033609. https://doi.org/10.1166/jnn.2008.432

4. Balog G, Voronezhskaya EE, Hiripi L, Elekes K (2012) Organization of the Serotonergic Innervation of theFeeding (Buccal) Musculature During the Maturation of the Pond Snail Lymnaea stagnalis: A Morphologicaland Biochemical Study. J Comp Neurol 520:315-329.

https://doi.org/10.1002/cne.22693

5. Baun A, Hartmann NB, Grieger K, Kusk KO (2008) Ecotoxicity of engineered nanoparticles to aquatic invertebrates: a brief review and recommendations for future toxicity testing. Ecotoxicology 17:387395. https://doi.org/10.1007/s10646-008-0208-y

6. Bayer MaterialScience (2007) Baytubes C 150 P: Preliminary Dara Sheet for Product Development

7. Bianco A, Kostarelos K, Prato M (2005) Applications of carbon nanotubes in drug delivery. Curr Opin Chem Biol 9:674-679. https://doi.org/10.1016/j.cbpa.2005.10.005

8. Bjorkland R, Tobias DA, Petersen EJ. (2017) Increasing evidence indicates low bioaccumulation of carbon nanotubes. Environ Sci: 4:747-766. https://doi.org/10.1039/C6EN00389C

9. Boer HH, Kits KS (1990) Histochemical and ultrastructural study of the alimentary tract of the freshwater snail Lymnaea stagnalis. Journal of Morphology 205:97-111.

https://doi.org/10.1002/jmor.1052050110

10. Borgmann, U. (1996) Systematic analysis of aqueous ion requirements of Hyalella azteca: A standard artificial medium including the essential bromide ion. Archives of Environmental Contamination and Toxicology 30(3):356-363. https://doi.org/10.1007/BF00212294

11. Buckley LJ (1984) RNA-DNA ratio: an index of larval fish growth in the sea. Mar. Biol. 80:291-298. https://doi.org/10.1007/BF00392824

12. Cano AM, Maul JD, Saed M et al. (2018) Trophic Transfer and Accumulation of Multiwalled Carbon Nanotubes in the Presence of Copper lons in Daphnia magna and Fathead Minnow (Pimephales promelas). Environ. Sci. Technol. 52:794-800. https://doi.org/10.1021/acs.est.7b03522

13. Carriker MR, Bilstad HM (1946) Histology of the alimentary system of the snail Lymnaea stagnalis appressa Say. Trans Amer Microsc 65(3):250-75

14. Characklis WG, Trulear MG, Bryers JD, Zelver1 N (1982) Dynamics of biofilm processes: methods. Water Research16: 1207-1216. https://doi.org/10.1016/0043-1354(82)90139-7

15. Chen KL, Smith BA, Ball WP, Fairbrother DH (2010) Assessing the colloidal properties of engineered nanoparticles in water: case studies from fullerene $\mathrm{C}-60$ nanoparticles and carbon nanotubes.

Environ Chem 7:10-27. https://doi.org/10.1071/EN09112 
16. Coeurdassier M, de Vaufleury A, Scheifler R, Morhain E, Badot PM (2004) Effects of cadmium on the survival of three life-stages of the freshwater pulmonate Lymnaea stagnalis (Mollusca: Gastropoda). Bull Environ Contam Toxicol 72:1083-1090. DOI: 10.1007/s00128-004-0354-8

17. Dobranskyte A, Jugdaohsingh R, Stuchlik E, Powell JJ, White KN, McCrohan CR (2004) Role of exogenous and endogenous silicon in ameliorating behavioural responses to aluminium in a freshwater snail. Environ Pollut 132:427-433. https://doi.org/10.1016/j.envpol.2004.05.023

18. Dobranskyte A, Jugdaohsingh R, McCrohan CR, Stuchlik E, Powell JJ, White KN (2006) Effect of humic acid on water chemistry, bioavailability and toxicity of aluminium in the freshwater snail, Lymnaea stagnalis, at neutral pH. Environ Pollut 140:340-347. https://doi.org/10.1016/j.envpol.2005.06.030

19. Elangovan R, White KN, McCrohan CR (1997) Bioaccumulation of aluminium in the freshwater snail Lymnaea stagnalis at neutral pH. Environ Pollut 96:29-33. https://doi.org/10.1016/S02697491(97)00009-2

20. Elangovan R, McCrohan CR, Ballance S, Powell JJ, White KN (2000) Localization and fate of aluminium in the digestive gland of the freshwater snail Lymnaea stagnalis. Tissue Cell 32:79-87. https://doi.org/10.1054/tice.1999.0089

21. Elser JJ, Schampel JH, Kyle M, Watts J, Carson EW, Dowling TE, TANG C, ROOPNARINE PD (2005) Response of grazing snails to phosphorus enrichment of modern stromatolitic microbial communities. Freshwater Biology 50:1826-1835. doi:10.1111/j.1365-2427.2005.01453.x

22. Feiyue W, Goulet RR, Chapman PM (2004) Testing sediment biological effects with the freshwater amphipod Hyalella azteca. Chemosphere 57:1713-1724. https://doi.org/10.1016/j.chemosphere.2004.07.050

23. Fidder BN, Reategui-Zirena EG, Olson AD, Salice CJ (2016) Energetic endpoints provide early indicators of life history effects in a freshwater gastropod exposed to the fungicide, pyraclostrobin. Environ Pollut 211:183-190. https://doi.org/10.1016/j.envpol.2015.12.018

24. Foth $\mathrm{H}$, Hayes AW (2008) Concept of REACH and impact on evaluation of chemicals. Human \& Experimental Toxicology 27:5-21. https://doi.org/10.1177/0960327107087801

25. Garacci M., Barret M., Mouchet F., Sarrieu C., Lonchambon P., Flahaut E., Gauthier L., Silvestre J., Pinelli E. (2016) Few Layer Graphene sticking by biofilm of freshwater diatom Nitzschia palea as a mitigation to its ecotoxicity. CARBON 113:139-150. http://dx.doi.org/10.1016/j.carbon.2016.11.033

26. Glomstad B, Zindler F, Jenssen BM, Booth AM (2018) Dispersibility and dispersion stability of carbon nanotubes in synthetic aquatic growth media and natural freshwater. Chemosphere 201:269-277. https://doi.org/10.1016/j.chemosphere.2018.03.019

27. Gottschalk F, Sonderer T, Scholz RW, Nowack B (2009) Modeled environmental concentrations of engineered nanomaterials ( $\mathrm{TiO}(2), \mathrm{ZnO}, \mathrm{Ag}, \mathrm{CNT}$, Fullerenes) for different regions. Environ Sci Technol 43:9216-9222. https://doi.org/10.1021/es9015553

28. Griffit RJ, Brown-Peterson NJ et al (2011) Effects of chronic nanoparticulate silver exposure to adult and juvenile sheepshead minnows. Environ Toxicol Chem 31:160-167. 
https://doi.org/10.1002/etc.709

29. Hoppeler F, Winkelmann C, Becker J, Pauls SU (2018) Larval growth and metabolic energy storage of Micropterna lateralis (Trichoptera: Limnephilidae) in an intermittent stream: glycogen dominates in final instars. Hydrobiologia 806:175-185. https://doi.org/10.1007/s10750-017-3354-5

30. Hudson M L, Costello DM, Daley JM, Burton JrGA (2019) Species-Specific (Hyalella azteca and Lymnea stagnalis) Dietary Accumulation of Gold Nano-particles Associated with Periphyton. Bulletin of Environmental Contamination and Toxicology 103:255-260. https://doi.org/10.1007/s00128019-02620-2

31. Jugdaohsingh R, Campbell MM, Thompson RP, McCrohan CR, White KN, Powell JJ (1998) Mucus secretion by the freshwater snail Lymnaea stagnalis limits aluminium concentration of the aqueous environment. Environ Sci Technol 32:2591-2595.

32. Karnovsky M (1965) A formaldehyde-glutaraldehyde fixative of high osmolality for use in electron microscopy. J Cell Biol 27:137-138.

33. Jackson P, Raun JN, Baun A, Birkedal R, Kühnel D, Alstrup JK, Vogel U, Wallin H (2013). Bioaccumulation and ecotoxicity of carbon nanotubes. Chem Cent $\mathrm{J}$ 7:154. https://doi.org/10.1186/1752-153X-7-154

34. Klaine SJ, Alvarez PJJ, Batley GE, Fernandes TF, Handy RD, Lyon DY, Mahendra S, McLaughlin MJ, Lead JR, (2008) Nanomaterials in the environment: Behavior, fate, bioavailability, and effects. Environ Toxicol Chem 27:1825-1851. https://doi.org/10.1897/08-090.1

35. Kohušová K, Havel L, Vlasák P, Tonika J (2011) A Long-Term Survey of Heavy Metals and Specific Organic Compounds in Biofilms, Sediments, and Surface Water in a Heavily Affected River in the Czech Republic (2011). Environ Monit Assess 174:555-572. https://doi.org/10.1007/s10661-0101478-4

36. Koop J, Schäffer M, Ortmann C, Winkelmann C (2008) Towards environmental assessment of river ecosystems by analyzing energy reserves of aquatic invertebrates. Limnologica 38:378-387. https://doi.org/10.1016/j.limno.2008.05.004

37. Koop JHE, Winkelmann C, Becker J, Hellmann C, Ortmann C (2011) Physiological indicators of fitness in benthic invertebrates: a useful measure for ecological health assessment and experimental ecology. Aquat Ecol 45:547-559. https://doi.org/10.1007/s10452-011-9375-7

38. Kroll A, Matzke M, Rybicki M, Obert-Rauser P, Burkart C, Jurkschat $K$, Verweij R, Sgier L, Jungmann D, Backhaus T, Svendsen C (2016) Mixed messages from benthic microbial communities exposed to nanoparticulate and ionic silver: 3D structure picks up nano-specific effects, while EPS and traditional endpoints indicate a concentration-dependent impact of silver ions. Environ Sci Pollut Res 23:4218-4234. https://doi.org/10.1007/s11356-015-4887-7

39. Kurth T, Weiche S, Vorkel D, Kretschmar S, Menge A (2012) Histology of plastic embedded amphibian embryos and larvae. Genesis 50:235-250. https://doi.org/10.1002/dvg.20821

40. Lalah JO, Behechti A, Severin GF, Lenoir D, Günther K, KettrupA, Schramm KW (2003). The bioaccumulation and fate of a branched 14C-p-nonylphenol isomer in Lymnaea stagnalis L. L. 
Environ Toxicol Chem 22:1428-1436. https://doi.org/10.1002/etc.5620220703

41. Lance E, Josso C, Dietrich D, Ernst B, Paty C, Senger F, Bormans M, Gerard C (2010). Histopathology and microcystin distribution in Lymnaea stagnalis (Gastropoda) following toxic cyanobacterial or dissolved microcystin-LR exposure. Aquatic toxicology 98:211-220.

https://doi.org/10.1016/j.aquatox.2010.02.014

42. Lawrence JR, Waiser MJ, Swerhone GDW, Roy J, Tumber V, Paule A, Hitchcock AP, Dynes J J, Korbe DR (2016) Effects of fullerene (C60), multi-wall carbon nanotubes (MWCNT), single wall carbon nanotubes (SWCNT) and hydroxyland carboxyl modified single wall carbon nanotubes on riverine microbial communities. Environ Sci Pollut 23:10090-10102. https://doi.org/10.1007/s11356-0166244-x

43. Li D, Fortner JD, Johnson DR, Chen C, Li Q, Alvarez PJJ (2010) Bioaccumulation of C-14(60) by the Earthworm Eisenia fetida. Environ Sci Technol 44:9170-9175. https://doi.org/10.1021/es1024405

44. Long Z, Ji J, Yang K, Lin D, Wu F (2012) Systematic and Quantitative Investigation of the Mechanism of Carbon Nanotubes' Toxicity toward Algae. Environ Sci Technol 46: 8458-8466. https://doi.org/10.1021/es301802g

45. Maes HM, Stibany F, Giefers S, Daniels B, Deutschmann B, Baumgartner W, Schäffer A (2014a) Accumulation and distribution of multiwalled carbon nanotubes in zebrafish (Danio rerio). Environ Sci Technol 48:12256-12264. https://doi.org/10.1021/es503006v

46. Mathes (1997) Ökotoxikologische Wirkungsabschäitzung. Das Problem der Extrapolation auf Ökosysteme. In: UWSF - Z Umweltchem Ökotox 9, 17. https://doi.org/10.1007/BF02945927

47. Maurer-Jones MA, Gunsolus IL, Murphy CJ, Haynes CL (2013) Toxicity of Engineered Nanoparticles in the Environment. Anal Chem 85:3036-3049. https://doi.org/10.1021/ac303636s

48. McCauley E, MurdochWM, Nisbet RM, Gurney WSC (1990) The physiological ecology of Daphnia: Development of a model of growth and reproduction. Ecology 71:703-715. https://doi.org/10.2307/1940324

49. Melendez R, Melendez-Hevia E, Cascante M (1997) How Did Glycogen Structure Evolve to Satisfy the Requirement for Rapid Mobilization of Glucose? A Problem of Physical Constraints in Structure Building. Journal of Molecular Evolution volume 45:446-455. https://doi.org/10.1007/PL00006249

50. Mohamed AM, Geraerts WPM (1976) Glycogen degradation and the accumulation of compounds during anaerobiosis in the fresh water snail Lymnaea stagnalis. Netherlands Journal of Zoology 26:549-557. DOI: https://doi.org/10.1163/002829676X00217

51. Mortimer M, Petersen EJ, Buchholz BA, Orias E, Holden A (2016) Bioaccumulation of Multiwall Carbon Nanotubes in Tetrahymena thermophila by Direct Feeding or Trophic Transfer. Environ Sci Technol 50:8876-8885. https://doi.org/10.1021/acs.est.6b01916

52. Mueller NC, Nowack B (2008) Exposure modeling of engineered nanoparticles in the environment. Environ Sci Technol 42:4447-4453. https://doi.org/10.1021/es7029637

53. Nicolai A, Filser J, Lenz R, Bertrand C, Charrier M (2012) Quantitative Assessment of Hemolymph Metabolites in Two Physiological States and Two Populations of the Land Snail Helix pomatia. 
Physiol Bichem Zool 85:274-284. https://doi.org/10.1086/665406

54. Nisbet RM, Jusup M, Klanjscek T, Pecquerie L (2012) Integrating dynamic energy budget (DEB) theory with traditional bioenergetic models. J Exp Biol 215:892-902. https://doi.org/10.1242/jeb.059675

55. Nyström P, Pérez JR (1998) Crayfish predation on the common pond snail (Lymnaea stagnalis): the effect of habitat complexity and snail size on foraging efficiency. Hydrobiologia 368:201-208. https://doi.org/10.1023/A:1003266603371

56. OECD (2004) Test no. 202: Daphnia sp. Acute Immobilisation Test (OECD Publishing). OECD/OCDE 202. https://doi.org/10.1787/9789264069947-en. Accessed 28 August 2020

57. OECD (2016) Test No. 243: Lymnaea stagnalis Reproduction Test (OECD Publishing). OECD/OCDE 243 http://www.oecd.org/termsandconditions/. Accessed 28 August 2020

58. Orr MV, El-Bekai M, Lui M, Watson K, Lukowiak K (2007) Predator detection in Lymnaea stagnalis. J Exp Biol 210:4150-4158. https://doi.org/10.1242/jeb.010173

59. Parks AN, Portis LM, Schierz PA, Washburn KM, Perron MM, Burgess RM, Ho KT, Chandler GT, Ferguson PL (2013) Bioaccumulation and toxicity of single-walled carbon nanotubes to benthic organisms at the base of the marine food chain. Environ Toxicol Chem 32:1270-1277. https://doi.org/10.1002/etc. 2174

60. Peck MA, Buckley LJ, Caldarone EM, Bengtson DA (2003) Effects of food con-sumption and temperature on growth rate and biochemical-based indicators of growth in early juvenile Atlantic cod Gadus morhua and haddock Melanogrammus aeglefinus. Marine Ecology Progress Series 251:233243. DOI:10.3354/meps251233

61. Petersen EJ, Huang QG, Weber WJ (2008) Bioaccumulation of radio-labeled carbon nanotubes by Eisenia foetida. Environ Sci Technol 42:3090-3095. https://doi.org/10.1021/es071366f

62. Petersen EJ, Akkanen J, Kukkonen JVK, Weber WJ (2009) Biological Uptake and Depuration of Carbon Nanotubes by Daphnia magna. Environ Sci Technl 43: 2969-2975. https://doi.org/10.1021/es8029363

63. Petersen EJ, Zhang L, Mattison NT, O'Carroll DM, Whelton AJ, Uddin N, Nguyen T, Huang Q, Henry TB, Holbrook RD, Chen KL (2011) Potential release pathways, environmental fate, and ecological risks of carbon nanotubes. Environ Sci Technol 45:9837-9856. https://doi.org/10.1021/es201579y

64. Petersen EJ, Xanat FCD, Bucheli TD, Elliott LCC, Fagan JA, Gogos A, Shannon H, Kägi R, Mansfield E, Bustos AR M, Plata DL, Reipa V, Westerhoff P, Winchester RM (2016) Quantification of Carbon Nanotubes in Environmental Matrices: Current Capabilities, Case Studies, and Future Prospects. Environ Sci Technol 50:4587-4605. https://doi.org/10.1021/acs.est.5b05647

65. Piccinno F, Gottschalk F, Seeger S, Nowack B (2012) Industrial production quantities and uses of ten engineered

66. nanomaterials in Europe and the world. J Nanopart Res 14:1109. https://doi.org/10.1007/s11051012-1109-9 
67. Politowski I., Regnery P, Hennig M P, Siebers N, Ottermanns R, Schäffer A (2021a). Fate of weathered multi-walled carbon nanotubes in an aquatic sediment system. Chemosphere 277: 130319. https://doi.org/10.1016/j.chemosphere.2021.130319

68. Politowski I, Wittmers F, Hennig M P, Siebers N, Goffart B, Roß-Nickoll M, Ottermanns R, Schäffer A (2021b). A trophic transfer study: accumulation of multi-walled carbon nanotubes associated to green algae in water flea Daphnia magna. Nanolmpact 22: 100303. https://doi.org/10.1016/j.impact.2021.100303

69. Reaegui-Zirena EG, Fidder BN, Salice CJ (2016) A cost or a benefit? Counterintuitive effects of diet quality and cadmium in Lymnaea stagnalis. Ecotoxicology 25:1771-1781. https://doi.org/10.1007/s10646-016-1720-0

70. Reategui-Zirena EG, Salice CJ (2018) Parental Diet Affects Embryogenesis of the Great Pond Snail (Lymnaea stagnalis) Exposed to Cadmium, Pyraclostrobin, and Tributyltin. Environ Toxicol Chem 37:2428-2438. https://doi.org/10.1002/etc.4202

71. Rhiem S, Riding MJ, Baumgartner W, Martin FL, Semple KT, Jones KC, Schäffer A, Maes HM (2015) Interactions of multiwalled carbon nanotubes with algal cells: Quantification of association, visualization of uptake, and measurement of alterations in the composition of cells. Environmental Pollution 196:431-439. https://doi.org/10.1016/j.envpol.2014.11.011

72. Rybicki M, Winkelmann C, Hellmann C, Bartels P, Jungmann D (2012) Herbicide indirectly reduces physiological condition of a benthic grazer. Aquat Biol 17:153-166. DOI: https://doi.org/10.3354/ab00472

73. Schierz A, Espinasse B, Wiesner MR, Bisesi JH, Sabo-Attwood T, Ferguson PL (2014) Fate of single walled carbon nanotubes in wetland ecosystems. Environ-Sci Nano: 1:574-583. https://doi.org/10.1039/C4EN00063C

74. Schwab F, Bucheli TD, Lukhele LP, Magrez A, Nowack B, Sigg L, Knauer K (2011) Are Carbon Nanotube Effects on Green Algae Caused by Shading and Agglomeration? (2011) Environ Sci Technol 45: 6136-44. https://doi.org/10.1021/es200506b

75. Schwirn K, Völker D (2016) Nanomaterialien in der Umwelt: Aktueller Stand der Wissenschaft und Regulierungen zur Chemikaliensicherheit.

https://www.umweltbundesamt.de/publikationen/nanomaterialien-in-der-umwelt. Accessed 01 June 2020

76. Schulte S, Flemming H (2006) Ursachen der erhöhten Resistenz von Mikroorganismen in Biofilmen In: Chemie Ingenieur Technik. 78, Nr. 11, Weinheim, pp 1683-1689. https://doi.org/10.1002/cite.200600088

77. Sebastian V, Arruebo M, Santamaria J (2013) Reaction Engineering Strategies for the Production of Inorganic Nanomaterials In: small. Wiley-VCH Verlag GmbH \& Co. KGaA, Weinheim, pp 1-19. DOI: 10.1002/smll.201301641

78. Selck H, Handy RD, Fernandes TF, Klaine SJ, Peterson EJ (2016) Nanomaterials in the aquatic environment: A European Union-United States perspective on the status of ecotoxicity testing, 
research priorities, and challenges ahead. Environ Toxicol Chem 35:1055-1067. https://doi.org/10.1002/etc.3385

79. Sokolova IM, Frederich M, Bagwe R, Lannig G, Sukhotin AA (2012) Energy homeostasis as an integrative tool for assessing limits of environmental stress tolerance in aquatic invertebrates. Mar Environ Res 79:1-15. https://doi.org/10.1016/j.marenvres.2012.04.003

80. Stanley JK, Laird JG, Kennedy AJ, Steevens JA (2015) Sublethal effects of multiwalled carbon nanotube exposure in the invertebrate Daphnia magna. Environ Technol Chem 35:200-204. https://doi.org/10.1002/etc.3184

81. Sun TY, Gottschalk F, Hungerbuhler K, Nowack B (2014) Comprehensive probabilistic modelling of environmental emissions of engineered nanomaterials. Environ Pollut 185:69-76. https://doi.org/10.1016/j.envpol.2013.10.004

82. Van Leeuwen K (2003) Technical Guidance Document on Risk Assessment, TGD. In: Institute for Health an Consumer Protection, Commission Directive 93/67/EEC on Risk Assessment for new notified substances. European Commission Part II. Commission Regulation (EC) No 1488/94, pp 108-109

83. Tervonen K, Waissi G, Petersen EJ, Akkanen J, Kukkonen JVK (2010) Analysis of fullerene-C60 and kinetic measurements for its accumulation and depuration in Daphnia magna. Environ Toxicol Chem 29:1072-1078. https://doi.org/10.1002/etc.124

84. Venable and Coggeshall (1965) A Simplified lead citrate stain for use in electron microscopy. J Cell Biol 25:407-408. https://doi.org/10.1083/jcb.25.2.407

85. Verneuil L, Silvestre J, Mouchet F, Flahaut E, Boutonnet JC, Bourdiol F, Bortolamiol T, Baque' D, Gauthier L, Pinelli E (2015) Multi-walled carbon nanotubes, natural organic matter, and the benthic diatom Nitzschia palea: "A sticky story". Nanotoxicology 9:219-229. https://doi.org/10.3109/17435390.2014.918202

86. Walton RC, McCrohan CR, Livens FR, White KN (2009) Tissue accumulation of aluminium is not a predictor of toxicity in the freshwater snail, Lymnaea stagnalis. Environ. Pollut. 157:2142-2146. https://doi.org/10.1016/j.envpol.2009.02.009

87. Wang F, Guan W, Xu L, Ding Z, Ma H, Ma A, Terry N (2019) Effects of Nanoparticles on Algae: Adsorption, Distribution, Ecotoxicity and Fate. Appl Sci 9:1534. https://doi.org/10.3390/app9081534

88. Wang J, Wages M, Yu S, Maul JD, Mayer G, Hope-Weeks L, Cobb GP (2014) Bioaccumulation of fullerene (C60) and corresponding catalase elevation in Lumbriculus variegatus. Environ Toxicol Chem 33:1135-1141. https://doi.org/10.1002/etc.2540

89. Walker G (1970) The cytology, histochemistry, and ultrastructure of the cell types found in the digestive gland of the slug, Agriolimax reticulatus (Müller). Protoplasma 71:91-109. https://doi.org/10.1007/BF01294305

90. Werlin R, Priester JH et al (2011) Biomagnification of cadmium selenide quantum dots in a simple experimental microbial food chain. Nat Nanotechnol 6:65-71. https://doi.org/10.1038/nnano.2010.251 
91. Williams ES, Berninger JP, Brooks BW (2011) Application of chemical toxicity distributions to ecotoxicology data requirements under REACH. Environ Toxicol Chem 30:1943-1954. https://doi.org/10.1002/etc.583

92. Winkelmann C, Koop JHE (2007) The management of metabolic energy storage during the life cycle of mayflies: a comparative field investigation of the collector-gatherer Ephemera danica and the scraper Rhithrogena semicolorata. J Comp Physiol B, Biochem Syst Environ Physiol 177:119-128. https://doi.org/10.1007/s00360-006-0114-7

93. Worischka S, Hellmann C, Berendonk TU, Winkelmann C (2014) Fish predation can induce mesohabitat-specific differences in food web structures in small stream ecosystems. Aquat Ecol 48:367-378. https://doi.org/10.1007/s10452-014-9490-3

94. Zubrod JP, Bundschuh M, Feckler A, Englert D, Schulz R (2011) Ecotoxicological impact of the fungicide tebuconazole on an aquatic decomposer-detritivore system. Environ Toxicol Chem 30:2718-2724. https://doi.org/10.1002/etc.679

\section{Figures}

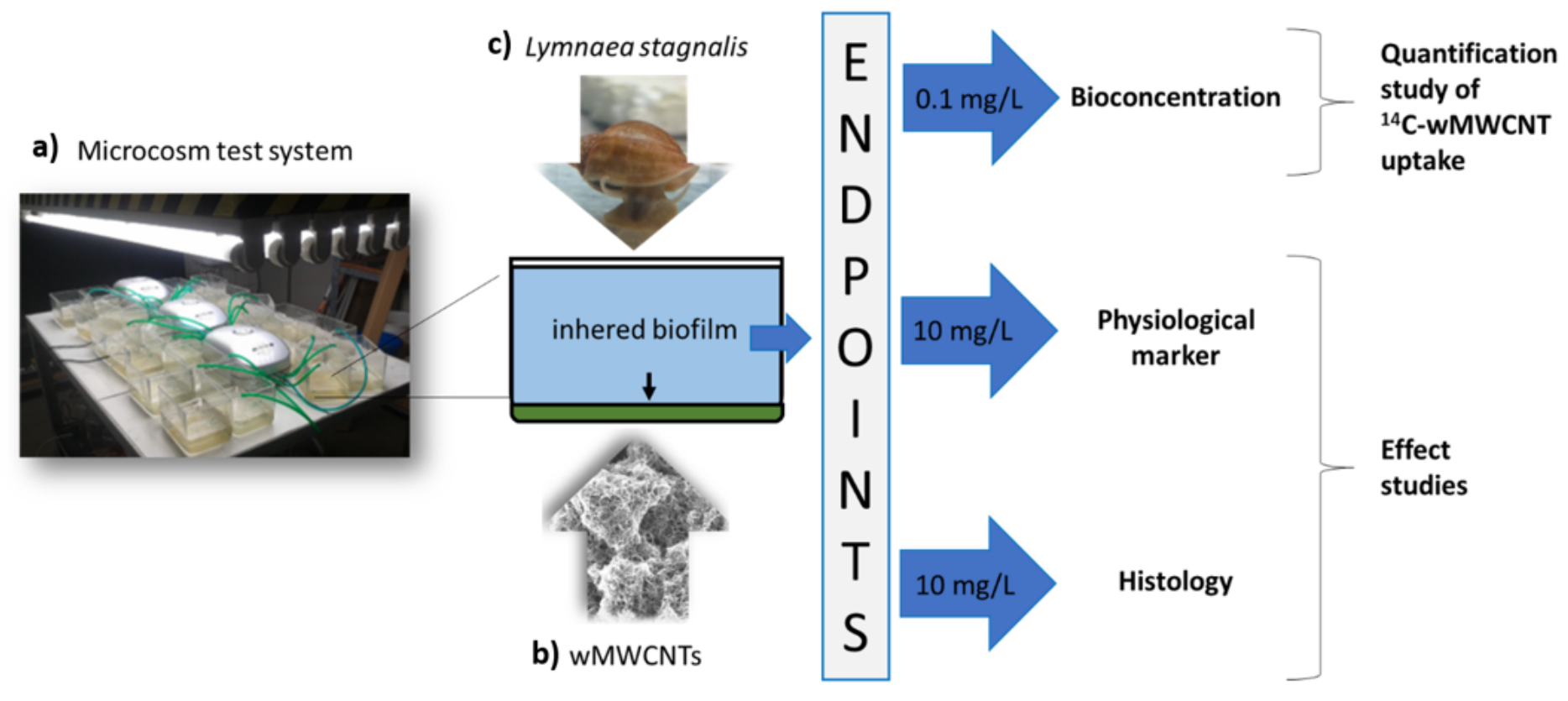

\section{Figure 1}

Overview of the whole workflow in the experimental set-up: a) microcosm, b) characterization of wMWCNTs (SEM, scale $1 \mu \mathrm{m}$ ), c) L. stagnalis (scale $1 \mathrm{~cm}$ ). Arrows indicates the different exposures of 0.1 and $10 \mathrm{mg} / \mathrm{L}$ together with the chosen methods in the quantification and effect study 


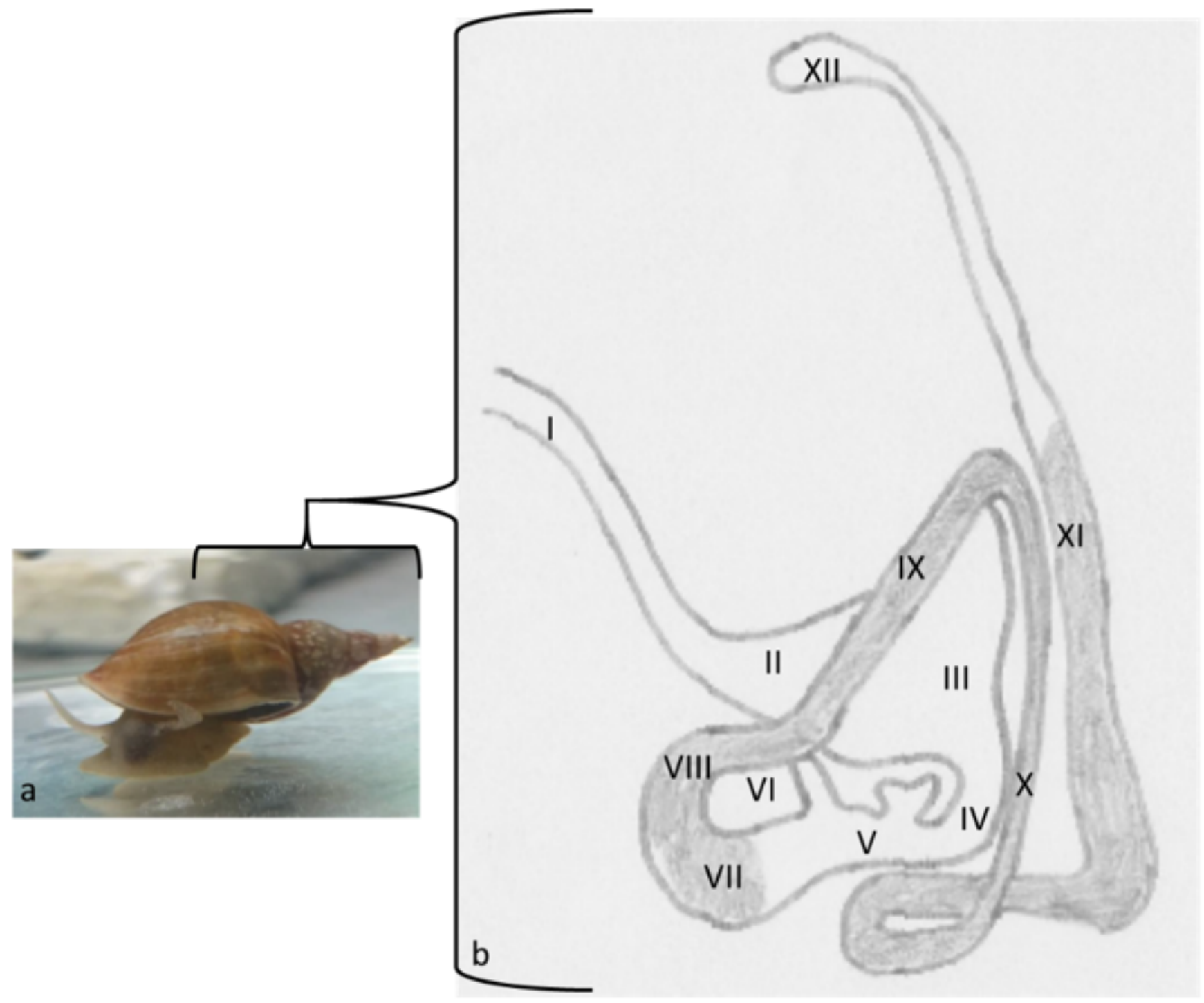

Figure 2

Depiction of L. stagnalis (a) and the associated sections of the alimentary tract (b). (I) postoesophagus, (II) crop, (III) gizzard, (IV) pylorus, (V) vestibulum with openings of the digestive gland ducts, (VI) coecum, (VII-IX) first to third part of prointestine, $(\mathrm{X})$ midintestine, $(\mathrm{XI})$ postintestine, $(\mathrm{XII})$ rectum. Reproduced according to Boer and Kits (1990) 

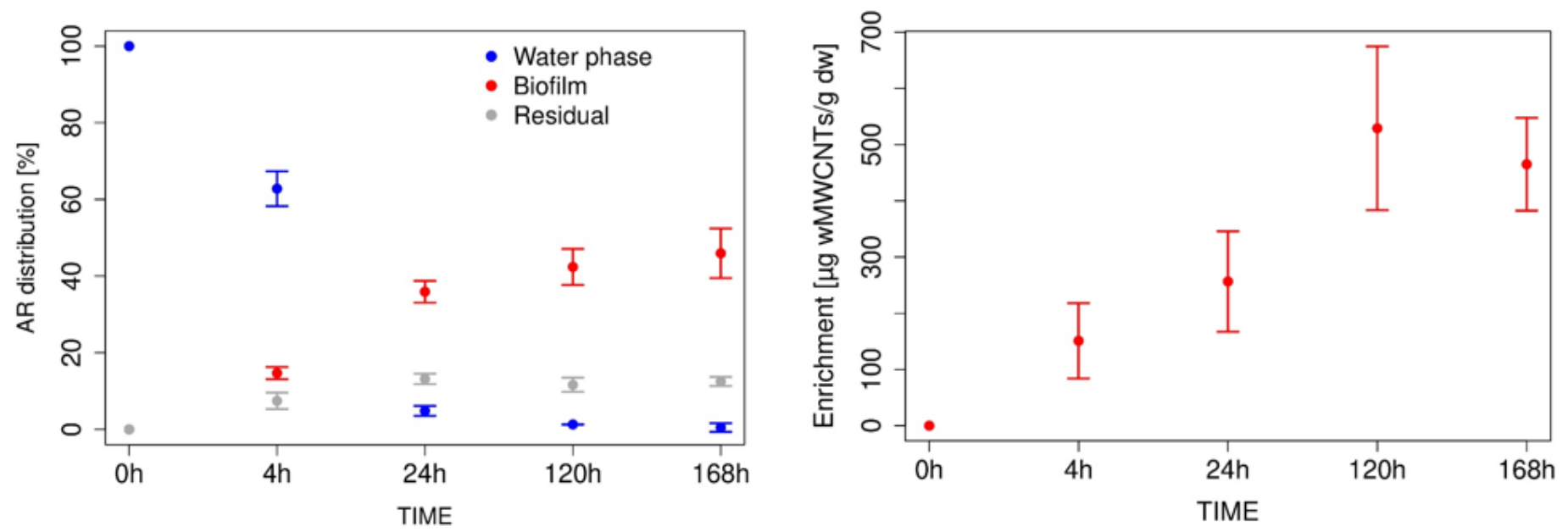

\section{Figure 3}

Left: Relative distribution: [\%] of AR in the different phases of the experimental set-up with benthic biofilm. Shown are the water phase (blue dots), biofilm (red dots) and residuals (grey dots) with mean. Right: Enrichment of the 14C-wMWCNTs in the benthic biofilm over time with mean and relative standard deviations. Note the non-linear time axis
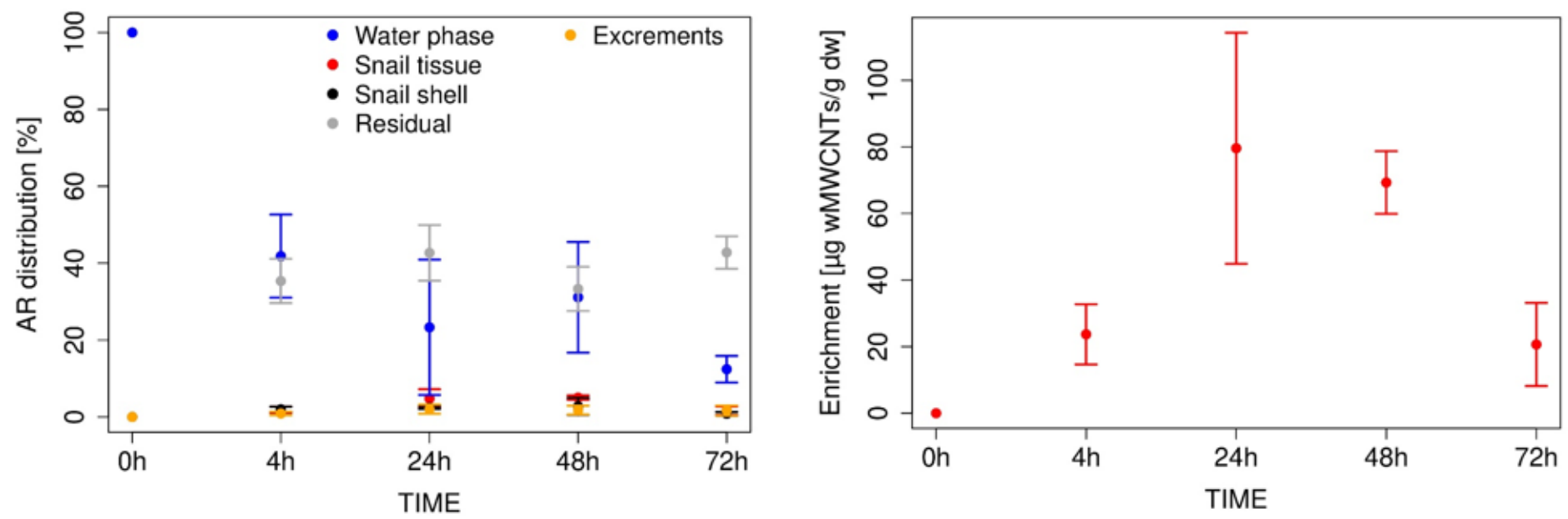

\section{Figure 4}

Left: Relative distribution: [\%] of AR in different compartments are shown as the water phase (blue dots), snail tissue (red dots), snail shell (black dots), excrements (yellow dots) and residuals (grey dots) with mean (of the experimental set-up for L. stagnalis [\%]. Right: Enrichment of the 14C-wMWCNTs in L. stagnalis tissue between time with mean and relative standard deviation 

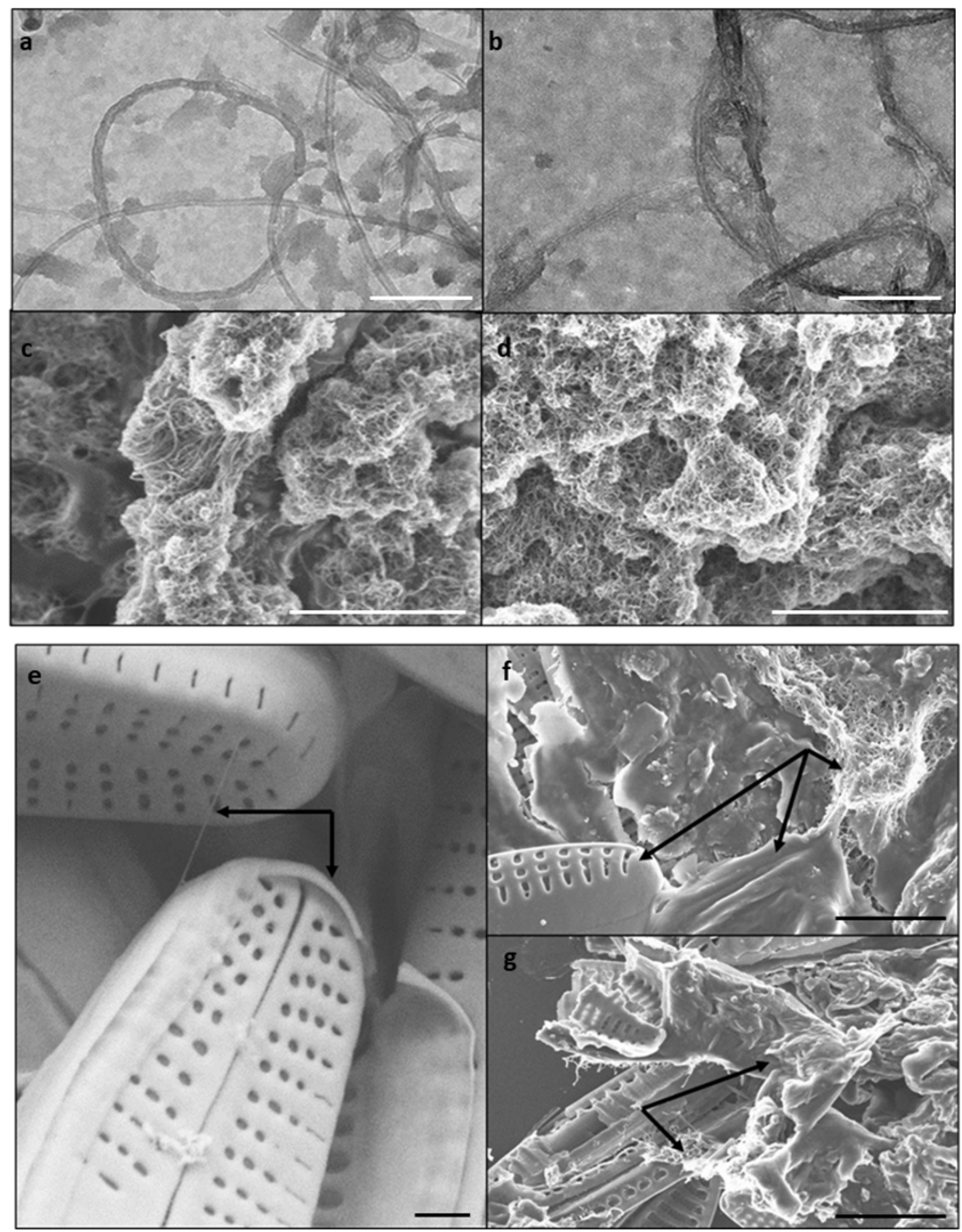

Figure 5

TEM (a-b) and SEM (c-g) images of wMWCNTs (a, c), MWCNTs (b, d) and of benthic biofilm after one week of exposure to $0.1 \mathrm{mg} / \mathrm{L}$ wMWCNTs (e-g) with (e) diatoms with an interacting EPS among themselves, $(f-g)$ diatoms with wMWCNTs and EPS interacting network. Scale bars indicate $200 \mathrm{~nm}(\mathrm{a}, \mathrm{b})$, $1 \mu \mathrm{m}(\mathrm{c}, \mathrm{d}), 200 \mathrm{~nm}(\mathrm{e}), 1 \mu \mathrm{m}(\mathrm{f}, \mathrm{g})$ 

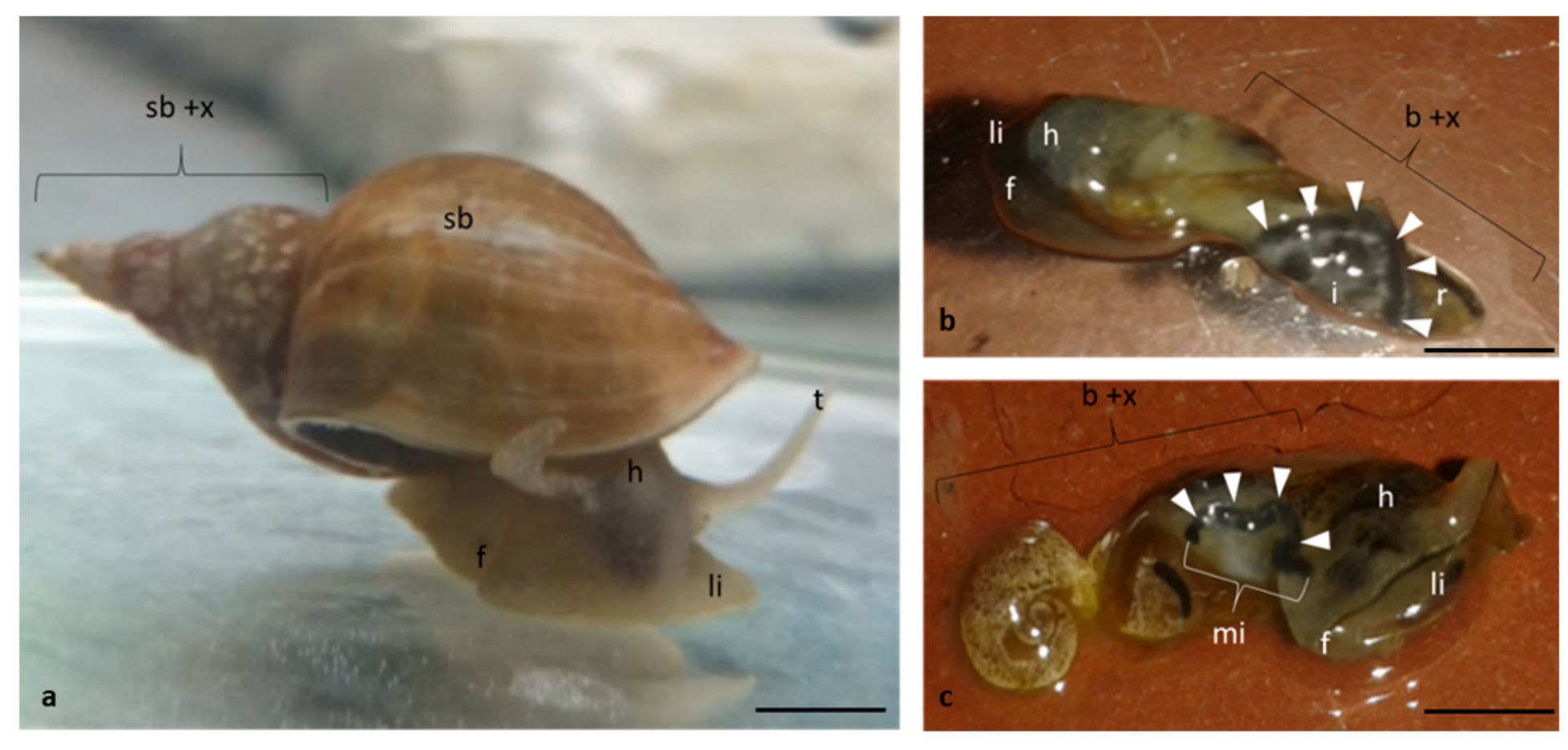

\section{Figure 6}

Pictures of L. stagnalis from control (a) and exposure (10 mg/L wMWCNTs) treatment after one week (bc). a) sb - shell-body, sb+x - parts of crop to rectum (see also Figure 2 ), $h$ - head, $t$ - tentacle, $f$ - foot, li - lips. The control is represented as whole individuum with the part $s b+x$ as the investigated area between crop till rectum where the intestine is in between. The treatments $(b-c)$ without shell where the intestine is visible as a black line (white arrowheads). $b$ ) $b+x-$ body without shell (parts from crop to rectum), $i-$ intestine; $c) b+x$ with additionally $\mathrm{mi}-$ midintestine. Scale bars indicate $1 \mathrm{~cm}(\mathrm{a}-\mathrm{c})$ 


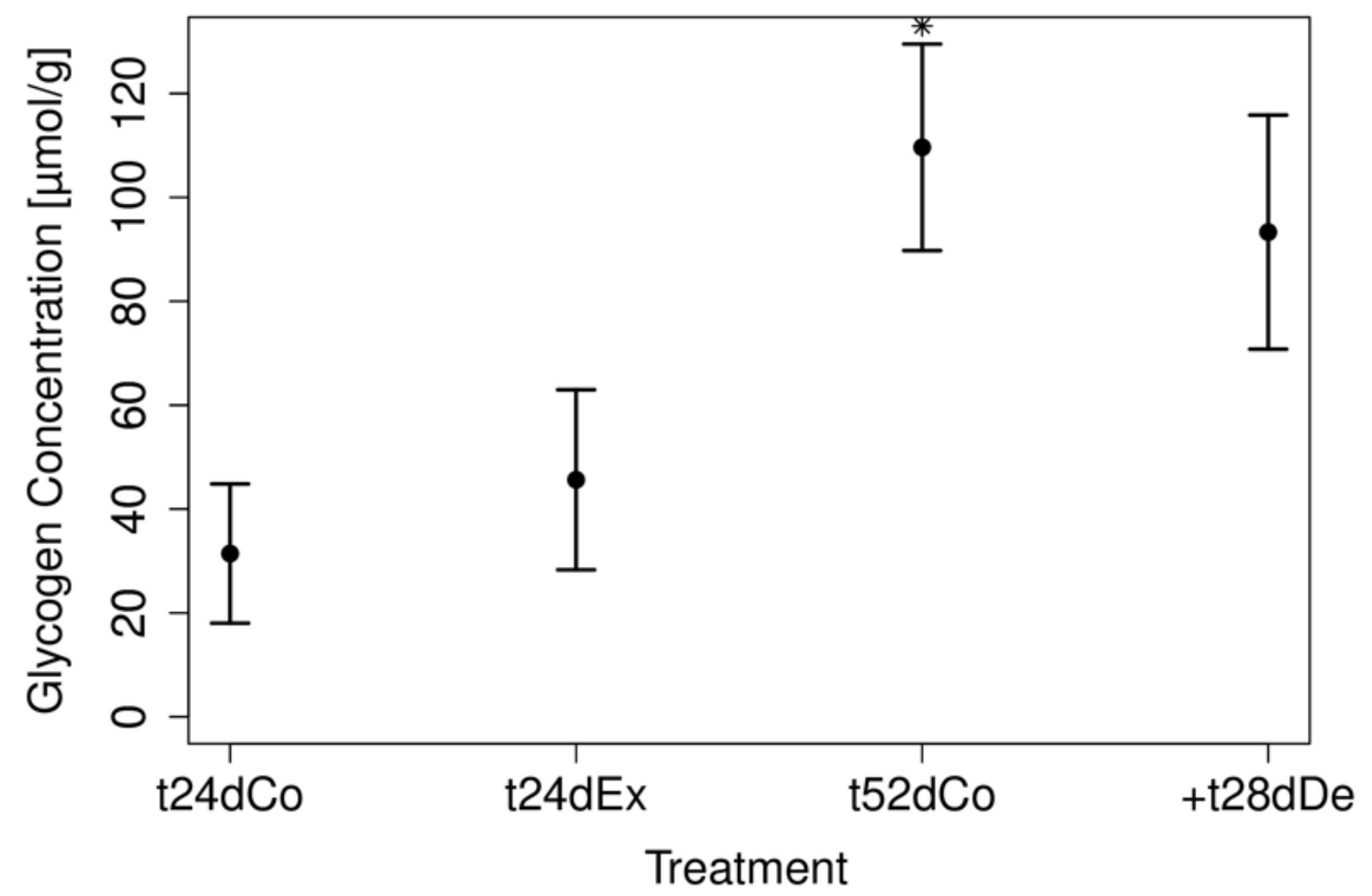

Figure 7

Results of the glycogen analysis after $24 \mathrm{~d}$ and $52 \mathrm{~d}$ with mean and relative standard deviation. The controls are depicted after $24 \mathrm{~d}$ as $\mathrm{t} 24 \mathrm{dCo}$, the control after $52 \mathrm{~d}$ as t52dCo. The exposures are depicted after the $24 \mathrm{~d}$ with wMWCNT as t24dEx and depuration after $28 \mathrm{~d}$ as $+\mathrm{t} 28 \mathrm{dDe}, \mathrm{p}^{\star}=0.03, \mathrm{n}=4$ 


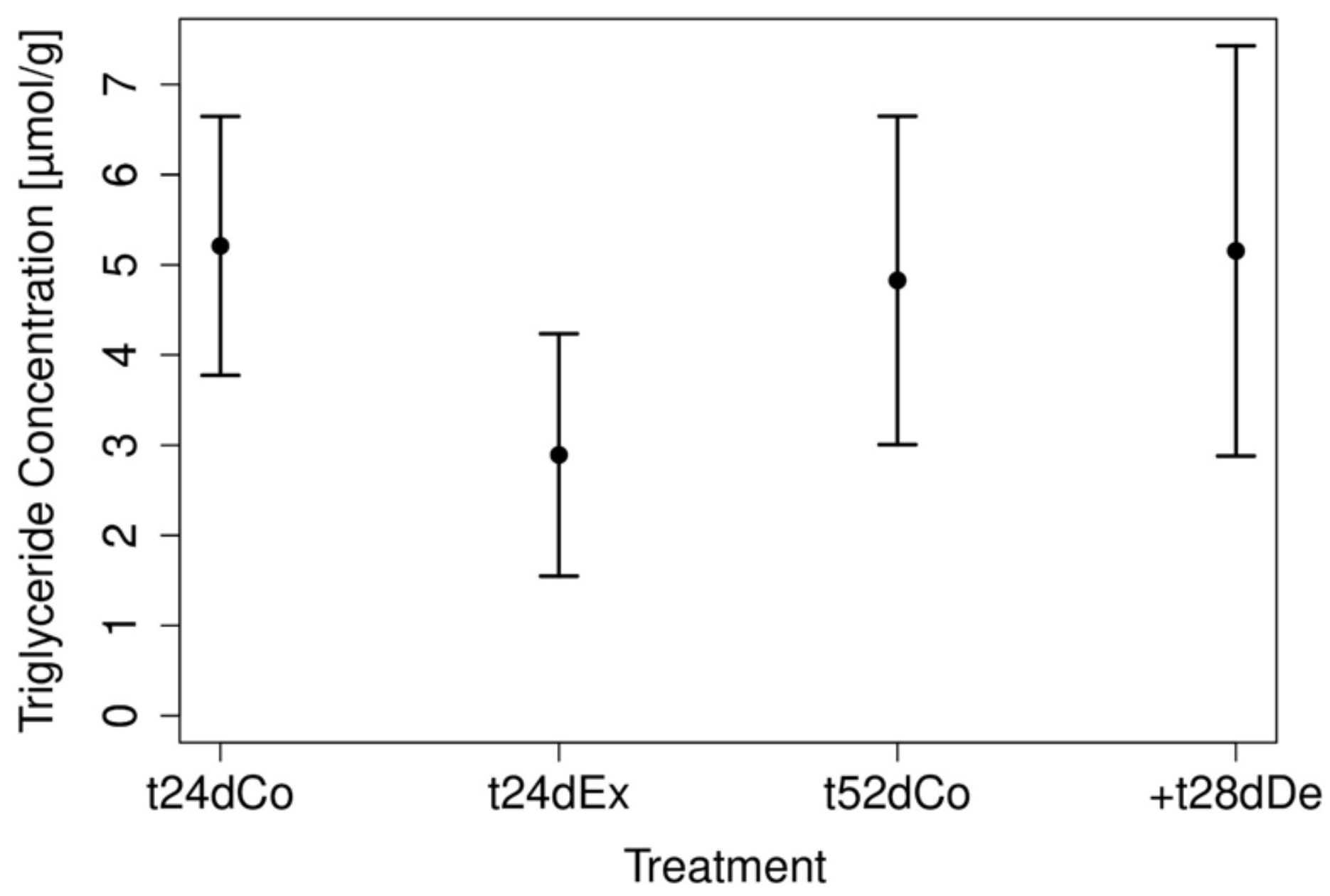

Figure 8

Results of the TGs analysis after $24 \mathrm{~d}$ and $52 \mathrm{~d}$ with mean and relative standard deviation. The controls are depicted after $24 \mathrm{~d}$ as $\mathrm{t} 24 \mathrm{dCo}$, the control after $52 \mathrm{~d}$ as $\mathrm{t} 52 \mathrm{dCo}$. The exposures are depicted after the $24 \mathrm{~d}$ with wMWCNT as t24dEx and depuration after $28 \mathrm{~d}$ as $+\mathrm{t} 28 \mathrm{dDe}, \mathrm{n}=4$ 


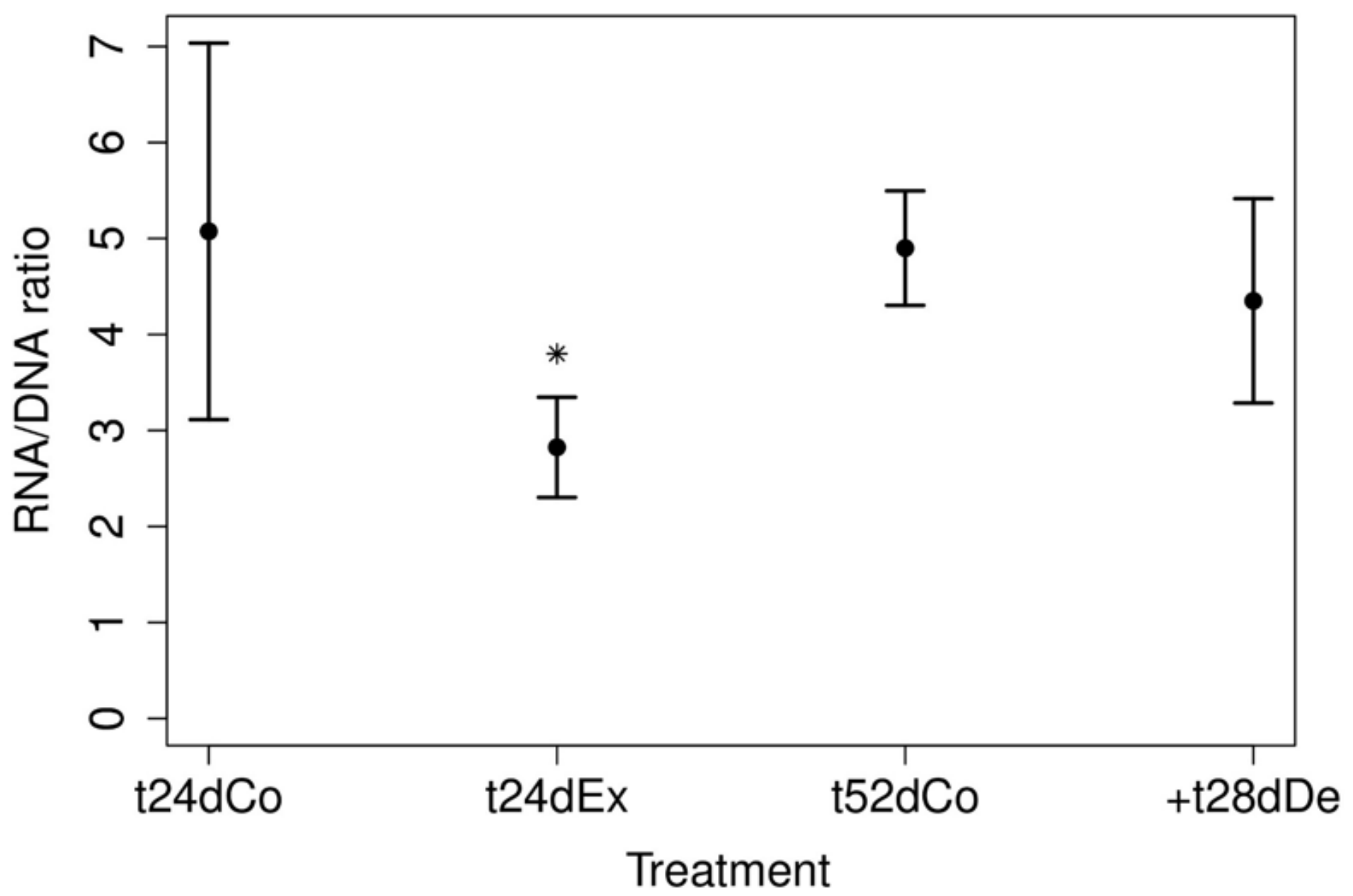

Figure 9

Results of the RNA/DNA analysis after $24 \mathrm{~d}$ and $52 \mathrm{~d}$ with mean and relative standard deviation. The controls are depicted after $24 \mathrm{~d}$ as $\mathrm{t} 24 \mathrm{dCo}$, the control after $52 \mathrm{~d}$ as t52dCo. The exposures are depicted after the $24 \mathrm{~d}$ with wMWCNT as t24dEx and depuration after $28 \mathrm{~d}$ as $+\mathrm{t} 28 \mathrm{dDe}, \mathrm{p}^{\star}=0.01, \mathrm{n}=4$ 


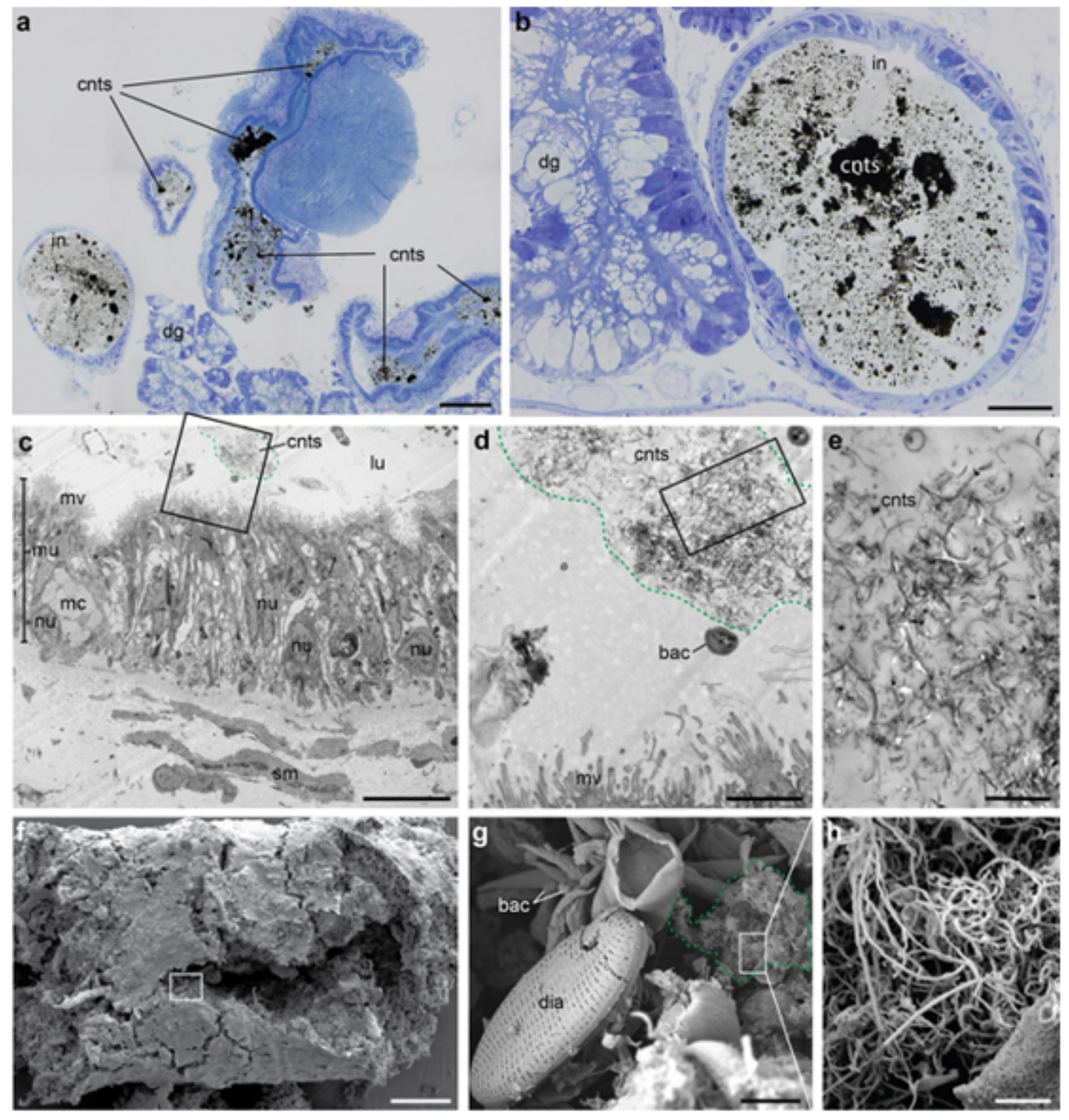

\section{Figure 10}

Histology and electron microscopy of wMWCNTs in the intestinal tract of L. stagnalis. a,b) Toluidine blue/borax stained methacrylate resin sections. An overview of different parts of the intestinal tract with wMWCNTs in the lumen (cnts). b) higher magnification of intestine (in) and adjacent digestive gland (dg). Bundles of wMWCNTs are clearly visible as black masses in the lumen of the intestinal tube. c-e: TEM of ultrathin epon sections through the intestinal wall. c) overview with lumen (lu), mucosa (mu), and underlying submucosa with smooth muscle cells (sm). A bundle of CNTs is visible in the lumen. The square indicates the region shown in $\mathrm{d}$. $d$ ) the CNT bundle at higher magnification in the vicinity of the apical microvilli of the enterocytes, the square indicates the region shown in e. e) CNTs at high magnification. f-h: SEM, f) intestinal content that was squeezed out of the intestinal tube. g) Intestinal content containing bacteria, algae (diatom, dia), and CNTs (surrounded by a green dashed line). The squares in $\mathrm{f}$ and $\mathrm{g}$ indicate the regions magnified in $\mathrm{g}$ and $\mathrm{h}$, respectively. $\mathrm{h}$ ) CNTs at high magnification. 
Further abbreviations: mc, mucus producing cell (goblet cell), nu, nucleus. Scale bars indicate $200 \mu \mathrm{m}(\mathrm{a})$, $50 \mu \mathrm{m}$ (b), $10 \mu \mathrm{m}$ (c), $2 \mu \mathrm{m}$ (d), $500 \mathrm{~nm}$ (e), $100 \mu \mathrm{m}$ (f), $5 \mu \mathrm{m}$ (g), and $500 \mathrm{~nm}(\mathrm{~h})$ 